\title{
Punishment, Deterrence and Social Control: The Paradox of Punishment in Minority Communities $^{\dagger}$
}

\author{
Jeffrey Fagan* and Tracey L. Meares**
}

Since the early 1970s, the number of individuals in jails and state and federal prisons has grown exponentially. Today, nearly two million people are currently incarcerated in state and federal prisons and local jails. The growth of imprisonment has been borne disproportionately by. African-American and Hispanic men from poor communities in urban areas. Rising incarceration should have greatly reduced the crime rate. After all, incapacitated offenders were no longer free to rob, assault, steal, or commit other crimes. However, no large-scale reduction in crime was detected until the mid-1990s. The failure of crime rates to decline commensurately with increases in the rate and severity of punishment reveals a paradox of punishment: recent experiments have shown that among persons of color, especially those who are poor or reside in poor neighborhoods, harsher punishment has produced iatrogenic or counterdeterrent effects.

We identify two processes that produce punishment paradoxes or defiance of legal sanctions. First, the long-term and spatially concentrated shift of social and economic resources from informal social controls to formal legal controls, particularly incarceration, weakens localized informal social controls and creates recurring cycles of discontrol. Neighborhood and work contexts offer social status and mete out shame and social opprobria for wrongdoing. However, stable rates of inequality and deprivation in minority communities compromise three dimensions of social control: social capital or regulation, "stakes in conformity" through marriage and work, and participation in political institutions. Second, high rates of punishment produce "stigma erosion" where punishment loses its contingent value that lends credibility to its claims of fairness and proportionality. As the social and cultural

$\dagger$ Thanks to Dan Kahan, Owen Fiss, Tom Tyler, and workshop participants at the University of Chicago School of Law, Columbia Law School, and the Harry Frank Guggenheim Foundation Punishment Working Group, for helpful comments on earlier drafts. Excellent research assistance was provided by Mukul Bakshi and Rubina Madni.

- Professor of Law and Public Health, Columbia University; Director, Center on Crime, Community and Law, Columbia Law School.

* Walton Hale Hamilton Professor of Law, Yale Law School; Senior Research Fellow, Berkeley Center for Criminal Justice. 
distance between the punishers and the punished widens, respect for the legitimacy of punishment suffers. Dissatisfaction with both procedural and distributive justice can motivate legal cynicism and noncompliance, and these processes are intensified in contexts of weak social control and high legal control.

As legal control replaces informal social control, the state's role in socialization and the fostering of moral communities diminishes. The devolving of the public sector involvement in socialization further moots the reintegrative functions of punishment. This restructuring and devaluation of government, accompanied by the restructuring and fragmentation of economic activity in poor communities, complicates the achievement of a social consensus on the rationale of punishment in a broader context of social control, and limits the efficacy of informal processes of social regulation.

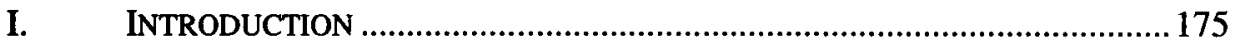

II. PUNISHMENT, DETERRENCE AND INFORMAL CONTROLS......................... 180

III. DETERRENCE AND THE STRUCTURAL CONTEXTS OF PUNISHMENT ........ 185

A. Community Social Organization .............................................. 186

B. Communities of Limited Liability................................................. 190

C. The Social Meaning and Economic Structure of Work................ 192

D. The Devaluation of Family .......................................................... 196

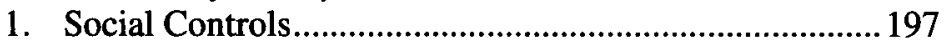

2. Social Networks and Social Isolation .............................. 198

3. Social Capital ............................................................201

IV. THE PARADOXICAL EFFECTS OF FORMAL PUNISHMENT ON SOCIAL

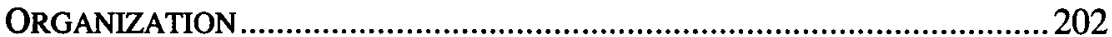

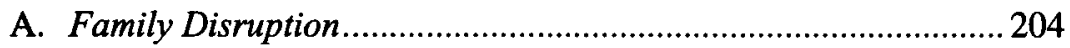

B. Low Economic Status and Joblessness ........................................206

V. THE IMPACT OF FORMAL PUNISHMENT AND PERCEPTIONS OF

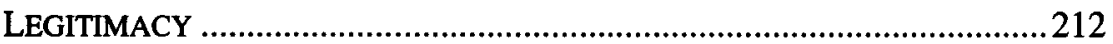

A. Stigma

B. Linked Fate and Multiple Roles..............................................222

VI. DETERRENCE AND THE POLITICS OF PUNISHMENT .................................224

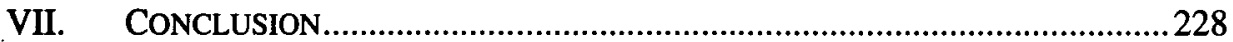




\section{INTRODUCTION}

Beginning in the $1980 \mathrm{~s}$ and continuing today, the number of persons incarcerated in the U.S. increased massively, incapacitating many criminals and increasing the risk of punishment for those still active. ${ }^{1}$ Between 1975 and 1989 , the total annual prison population of the United States nearly tripled, growing from 240,593 to 683,367 inmates in custody, an increase of $184 \% .^{2}$ The trend continued uninterrupted, albeit at a slower pace, through 2006, when the prison population rose to $1,492,973 .^{3}$ Put another way, the incarceration rate rose from about 145 per 100,000 population in 1980 to 499 per 100,000 in $2006 .^{4}$ Both the likelihood of being committed to prison, and the average sentence length of those committed, increased dramatically over that time. ${ }^{5}$ These factors should have greatly reduced the crime rate.

Punishment on a scale of this sort had never before been attempted or achieved in the United States, and its proponents anticipated large reductions in crime rates. After all, the large number of active offenders incapacitated were no longer free to rob, assault, steal, or commit other crimes-at least against those outside of penitentiary walls. Also, a downward demographic bulge in the 1980s shrunk the population group whose crime rates traditionally have been highest, reducing the pool of potential replacements for incarcerated offenders. Deterrence theory suggested that would-be offenders were likely to rate the likely punishment costs of crime as significantly higher, reducing their incentives to risk imprisonment for highly variable gains from crime. And, there was also reason to think that at least some would-be offenders were getting the message as the rhetoric of punishment escalated during this time. Well-publicized legal reforms and popular culture communicated new messages of intolerance for crime and threats of new draconian forms of punishment.

1 See Alfred Blumstein \& Allen J. Beck, Population Growth in U.S. Prisons, 1980-1996, in PRISONS 17 (Michael Tonry \& Joan Petersilia eds., 1999); Jacqueline Cohen \& Jose A. CanelaCacho, Incarceration and Violent Crime: 1965-1988, in UNDERSTANDING AND PREvenTING VIOLENCE 296 (Albert J. Reiss, Jr. \& Jeffrey A. Roth eds., 1994); Steven D. Levitt, The Effect of Prison Population Size on Crime Rates: Evidence from Prison Overcrowding Litigation, 111 Q. J. ECON. 319 (1996).

2 See Bureau of Just. Stat., U.S. Dep't of Just., Correctional Populations in the UNITED STATES, 1996 (1999).

3 Bureau OF JuSt. STAT., U.S. DeP'T OF JuST., CoRrectional SURVEYs (2005), available at http://www.ojp.usdoj.gov/bjs/glance/tables/corr2tab.htm. See also Blumstein \& Beck, supra note 1, at 22 (citing data from the BUREAU OF JUST. STAT., supra note 2, and the Bureau of the Census (various years)).

4 Blumstein \& Beck, supra note 1, at 18. This includes both state and federal prisoners but excludes persons in county jails. I took the $1,492,973$ prison population information data and divided it by the population of $298,754,819$, as estimated by the U.S. Census Bureau for July 2006, available at http://www.census.gov/popest/states/NST-ann-est.html.

5 See generally MARC MAUER, RACE to InCARCERATE (1999); BRUCE Western, PUNISHMENT AND INEQUALITY IN AMERICA (2006). 
Despite the many reasons to expect significant crime reduction from the expansion in punishment, no large-scale reduction in crime was detected. Through the early 1990s, both officially recorded crime and self-reports of victimization failed to decline even as the incarceration rate increased. ${ }^{6}$ Homicides rose steadily in U.S. cities beginning in 1985, with record rates measured nationally as well as in fourteen large cities in 1991. ${ }^{7}$ Other crimes remained stable, while the victimization rate declined only slightly. ${ }^{8}$ Although crime rates have declined in recent years from their peak in the early 1990s, they remain at high levels in the face of increasing costs of crime, especially considering the unprecedented increases in incarceration rates in recent decades.

The failure of crime rates to decline commensurately with increases in the rate and severity of punishment reveals a paradox of punishment: higher incarceration rates resulted in stable if not higher levels of crime.

Several explanations could be fashioned. First, despite the stochastic selectivity of incarceration policies (that is, the highest rate offenders were likely to be over-represented among prison populations), only modest incapacitation effects, estimated at less than ten percent of potential violent crimes, were achieved. ${ }^{9}$ This means that in order to achieve measurable decreases in crime through incapacitation, we would have to further commit to an unrealistically expensive increase in incarceration rates. ${ }^{10}$

Second, it is possible that punishment backfired. That is, there is growing evidence from several small-scale studies that incarceration may have iatrogenic effects with respect to offending rates. ${ }^{11}$

6 See Mauer, supra note 5; Michael TonRy, Malign Neglect-Race, Crime, and PUnishment in AMERICA (1995); Frankin E. ZIMRING \& GoRdon HaWkINS, InCAPACITATION: Penal Confinement and The Restraint of Crime (1995); Richard B. Freeman, Why Do So Many Young American Men Commit Crimes and What Might We Do About It?, 10 J. ECON. PERSP. 25 (1996).

See Frankin E. Zimring \& Gordon hawkins, Crime Is Not the Problem: Lethal VIOLENCE IN AMERICA (1997); Phillip J. Cook \& John H. Laub, The Unprecedented Epidemic in Youth Violence, in YOUTH VIOLENCE 27 (Michael Tonry \& Mark H. Moore eds., 1998).

8 See Zimring \& HaWkINS, supra note 6; Cohen \& Canela-Cacho, supra note 1.

9 See Cohen \& Canela-Cacho, supra note 1, at 371 n.56. Even as crime rates have declined from their peaks in the early 1990 s, incarceration played a minor role in that reduction. The "66percent increase in the state prison population, from 725,000 to more than 1.2 million prisoners reduced the rate of serious crime by 2 to 5 percent-one-tenth of the fall in crime between 1993 and 2001. Fully 90 percent would have happened without the 480,000 new inmates in the system." WESTERN, supra note 5, at 186-87.

10 See Cohen \& Canela-Cacho, supra note 1. They claim that the prison population would have to nearly triple before crime declines would increase to 20 percent.

11 See, e.g., Jeffrey A. Fagan, Do Criminal Sanctions Deter Drug Crimes?, in DRUGS AND CRIME 188 (Doris Layton MacKenzie \& Craig D. Uchida eds., 1994); Jeffrey Fagan, The Comparative Advantage of Juvenile Versus Criminal Court Sanctions on Recidivism among Adolescent Felony Offenders, 18 LAW \& PoL'y 77 (1996); Lawrence W. Sherman, Defiance, Deterrence and Irrelevance: $A$ Theory of the Criminal Sanction, 30 J. RES. CRIME \& DELINQ. 445 (1993). 
Third, motivations and incentives among would-be offenders for crime commission may have increased over this period, or the general and specific deterrent effects of incarceration may have been weak or ineffective. ${ }^{12}$ Under this scenario, less active offenders replaced incarcerated ones at the higher offending rates; those released from prison quickly returned to crime at rates equal to or higher than before; and, quite possibly, new people joined the ranks of offenders. ${ }^{13}$

Whatever the effects, the lack of further crime reductions over a period of expanding incarceration suggest that punishment was ineffective, irrelevant, or even provocative with respect to crime. ${ }^{14}$

The story we tell in this essay is not confined to an explanation of this punishment paradox, however. Rather, we emphasize the special impact that the dramatic increase in punishment has had on African Americans. While the increase in American punishment is impressive as a general matter, the involvement of African Americans is staggering. ${ }^{15}$ The growth in incarceration, by population especially but also by rates, has been far greater for African Americans than for any other ethnic or racial group. ${ }^{16}$ A few statistics illustrate: While the number of African Americans incarcerated in state correctional facilities has long been disproportionate to the percentage of African Americans in the population, African Americans comprised $45 \%$ of state prison populations. ${ }^{17}$ From 1980 to

12 See Daniel S. Nagin, Criminal Deterrence Research at the Outset of the Twenty-First Century, 23 CRIME \& JUST. 1 (1998) (discussing the loss of contingent threat of criminal punishment under conditions of mass incarceration).

13 See Freeman, supra note 6.

14 But see Levitt, supra note 1 (showing deterrent effects of incarceration based on natural experiments of states that have released offender cohorts following litigation and court intervention).

15 Robert J. Sampson \& Janet Lauritsen, Racial and Ethnic Disparities in Crime and Criminal Justice in the United States, in ETHNICITY, CRIME AND IMMIGRATION: COMPARATIVE AND CROSSNATIONAL PERSPECTIVES 311 (Michael Tonry ed., 1997).

16 See Blumstein \& Beck, supra note 1; DAvid Cole, No EQUAL JustiCE: RACE AND Class in THE AMERICAN CRIMINAL JUSTICE SYSTEM (2000); MAUER, supra note 5; TONRY, supra note 6 (claiming that racial animus in the development of law and policy since the early 1970s has fueled disparate trajectories of incarceration by race).

17 For a historical look at racial differences in incarceration, see TONRY, supra note 6; Samuel L. Myers, Jr. \& William J. Sabol, Unemployment and Racial Differences in Imprisonment, in THE ECONOMICS OF RACE AND CRIME 189, 194 (Margaret C. Simms \& Samuel L. Myers, Jr. eds., 1988); (demonstrating average incarceration rates, by decade, of whites and blacks from 1850 to 1980). In 2005 , blacks represented $39.5 \%$ and whites represented $34.6 \%$ of the prison populations. BUREAU OF JUST. STAT., U.S. DEP'T OF JUST., PRISONERS IN 2005, at 8 (2006), available at http://www.ojp.usdoj.gov/bjs/pub/pdf/p05.pdf. In 1993, Blacks represented 49.7\% of the state prison population and $33.7 \%$ of the federal population, while Whites represented $45.6 \%$ and $63.1 \%$, respectively. See Bureau of Just. Stat., U.S. DeP'T OF Just., Sourcebook of CRIMINal JuST. STAT. 1994, at 546 (1994). In December 2007, the Bureau of Justice Statistics released a report stating that from 2000 through 2006, the number of sentenced Black male prisoners increased slightly, from an estimated 528,300 to 534,200 but that the percentage of African-American men among all sentenced male prisoners actually declined to $38 \%$ from $43 \%$. BUREAU OF JUST. STAT., U.S. DEP'T OF JUST., PRISONERS IN 2006, at 7 (2007), available at http://www.ojp.usdoj.gov/bjs/pub/pdf/p06.pdf. 
2003, the number of African-American inmates in state and federal prisons rose from 145,300 to 577,100 , an increase of $297 \%$. The incarceration rate for African Americans rose from 554 per 100,000 persons in 1980 to 1,574 per 100,000 in 1996 , an increase of $184 \% .^{18}$ The rate increased to 2,531 per 100,000 in 2004 , an additional 61\% increase over eight years. ${ }^{19}$ The Sentencing Project, a nonprofit organization supporting alternatives to prison, studied the demographics of criminal justice control and recently estimated that nearly one third of young African-American men between the ages of twenty and twenty-nine are in prison, jail, or on probation or parole. ${ }^{20}$ Additional studies indicate that these numbers were as high as $40 \%$ of young African-American men in the cities of Baltimore and Washington, D.C. ${ }^{21}$ The number of such supervised males exceeded the number who were legally working. ${ }^{22}$

These high rates of African-American involvement with the criminal justice system clearly are tied to drug offending. Data show that by 1993 drug offenders accounted for about one quarter of all prison and jail incarcerations, compared to 8.8\% one decade earlier, and African Americans have borne the brunt of law enforcement efforts targeted at illegal drug use and trafficking. ${ }^{23}$ Examination of

18 Blumstein \& Beck, supra note 1, at 22. By comparison, the increase in Hispanic sentenced prisoners was far greater, at $554 \%$, but their incarceration rate in 1996 was 690 per 100,000 residents, less than half the rate for African Americans. The number of White prisoners rose by $185 \%$ during this period, and the White incarceration rate rose by $164 \%$, but at 193 per 100,000 residents, it was less than one-eighth the African-American rate.

19 Prison POlicy INTIATIVE, U.S. INCARCERATION RATES BY RACE, http://www.prisonpolicy.org/graphs/raceinc.html (citing BUREAU OF JUST. STAT., U.S. DEP'T OF JUST., PRISON AND JAIL INMATES AT MIDYEAR 2004, available at http://www.ojp.usdoj.gov/bjs/abstract/pjim04.htm). See also BUREAU OF JUST. STAT., U.S. DEP'T OF JUST., PRISON AND JAIL INMATES AT MIDYEAR 2006, at 9 (2007), available at http://www.ojp.usdoj.gov/bjs/pub/pdf/pjim06.pdf, (listing rates of 4,789 incarcerated persons for every 100,000 African-American males and 358 incarcerated persons for every 100,000 AfricanAmerican females).

20 Marc Mauer \& Tracy Huling, The Sentencing Project, Young Black Americans and the Criminal Justice System: Five Years Later 3 (1995). See also Jeremy Travis, But THEY ALL COME BACK 24 (2005) ("In 2002, slightly more than 10 percent of African-American men between the ages of 25 and 29 years old were in prison, compared with 2.4 percent of Hispanic men and 1.2 percent of white men.").

21 See MAUER, supra note 5.

22 Id.

23 See, e.g., Ronald Weitzer \& Stephen A. Tuch, Racially Biased Policing: Determinants of Citizen Perceptions, 83 SOC. FORCES 1009 (2005) (presenting survey data showing that perceptions of racial bias by police are highest among African-American respondents than Hispanic respondents, but that both groups perceive higher rates of racial bias than do Whites, and that attitudes towards the legality and acceptance of racially-biased policing practices are largely shaped by citizens' race, personal experiences with police discrimination, and exposure to news media reporting on incidents of police misconduct); See also, MAUER \& HULING, supra note 20, at 11; See also TONRY, supra note 6. Drug offenders continue to represent about one-fifth of incarcerations. See BUREAU OF JUST. Stat., Prisoners in 2006, supra note 17 at 8; Marc MaUer \& Ryan S. King, The Sentencing Project, A 25-Year QUaGmire: The War on DRUGS and ITS IMPaCt on AMERICAN SOCIETY 2 
the Bureau of Justice Statistics Surveys of Inmates of State Correctional Facilities for 1979, 1986, and 1991 reveals that the number of African-American prisoners incarcerated for drug offenses jumped from 13,974 in 1986 to 73,932 in 1991, an increase of $429 \% .^{24}$ By 2003, 133,100 African Americans were incarcerated for drug offenses, an increase of $80 \%$ in twelve years. ${ }^{25}$ From 1980 to 1996 , incarceration rates for African Americans for drug offenses increased an average of $20.3 \%$ annually, compared to $12 \%$ for Whites and $16 \%$ for Hispanics. ${ }^{26}$ And, as the numbers of those incarcerated for drug offenses have grown over time, the racial gap in the demographics of prisoners has widened. ${ }^{27}$ Analysis of Bureau of Justice Statistics data indicates that incarceration for drug offenses of African Americans with less than a high school education increased from 60 in 100,000 in 1979 to 800 in 100,000 in 1991 . The same rates for Whites with a high school education increased from 6 in 100,000 in 1979 to 20 in 100,000 in $1991^{28}$ Accordingly, one cannot discuss the rise of American imprisonment without a special look at African-American imprisonment and punishment generally. The aim of this paper is to make sense of the punishment paradox and the experience of African Americans by exploring two questions. First, what has been the impact of the criminalization of African-American males on society as a whole and on the

(2007) (stating that there has been a $1100 \%$ increase in the amount of drug offenders in prisons and jails since 1990 and that 493,800 people are in prison for a drug offense, compared to 41,100 in 1980).

24 MAUER \& HUling, supra note 20, at 20.

25 BUREAU OF JUST. STAT., PRISONERS IN 2006, supra note 17, at 9.

26 Blumstein \& Beck, supra note 1, at 24-25. Note that the number of African Americans incarcerated in state prisons for drug convictions declined from 134,000 in 1995 to 133,100 in 2003. Bureau OF JUST. STAT., U.S. DeP'T OF JUST., PRISONERS IN 1996, at 10 (1997), available at http://www.ojp.usdoj.gov/bjs/pub/pdf/p96.pdf; BUREAU OF JUST. STAT., PRISONERS IN 2005, supra note 17 , at 9 . However, this decrease may have resulted in methodological changes, most notably separation of Hispanics in later data.

27 Among those convicted for drug offenses in state courts, 33\% of convicted White defendants versus $51 \%$ of African-American defendants received prison sentences. MATTHEW R. Durose \& Patrick A. Langan, U.S. Dep't of Just., State Court Sentencing of Convicted FELONS, 1998 Statistical TABles, Tbl. $2.5 \quad$ (2001), available at http:www.ojp.usdoj.gov/bjs/abstract/scsc98st.htm. Moreover, the cocaine-crack discrepancy has subverted the consistency that mandatory minimum sentences at the federal level were supposed to promote; in 1986, the average federal drug offense sentence was $11 \%$ longer for African Americans than for Whites. By 1990, African Americans faced an average sentence that was $49 \%$ longer than White federal drug offenders. See Barbara S. MEIERHOEFER, Fed. Jud. CTR., The General EFFECT OF MANDATORY MINIMUM PRISON TERMS 20 (1992). According to a 2003 report by the U.S. Department of Justice, 44\% of African-American inmates in 1997 did not complete high school or the GED, whereas $27 \%$ of White inmates did not complete high school or the GED. BUREAU OF Just. STAT., U.S. DEP'T OF Just., EdUCATION AND CORRECTIONAL POPUlations 6 (2003), available at http://www.ojp.gov/bjs/pub/pdf/ecp.pdf.

28 See Tracey L. Meares, Charting Race and Class Differences in Attitudes Toward Drug Legalization and Law Enforcement: Lessons for Federal Criminal Law, 1 BUFF. CRIM. L. REV. 137, 148 (1997). 
African-American communities from which these men come? Second, what is its impact on perceptions of African Americans of the legitimacy of our laws and legal institutions? Our thoughts on answers to these questions will unfold in four parts.

The first part lays out an explanation of the relationship between deterrence theory and social control. This part argues that our current "get tough" approach to crime control ignores the foundations of classical deterrence theory on which the policy presumably is premised, as classical deterrence theory pays much more attention to informal controls on individual behavior than our imprisonment policy does. The second part discusses the social contexts that can either enhance or detract from formal punishments. In this part we emphasize community social organization theory, and we demonstrate that African Americans, because they too often are situated in a community context that is very different from the context in which non-African Americans are situated, experience both crime and the policy that attempts to control crime in a unique way. The third part discusses the potential paradoxical effects of formal punishment and the unique consequences for predominantly minority communities where poverty is concentrated. The fourth part theorizes about reactions to law enforcement in minority communities. Here we emphasize how the escalation in formal punishment over the last two decades likely affects the commitment of residents of minority high-crime communities to government entities. The essay concludes with ideas about strengthening the legitimacy of law enforcement in distressed, predominantly minority communities.

\section{PUNISHMENT, DETERRENCE AND INFORMAL CONTROLS}

While deterrence theories have been implicit in writings about punishment for centuries, the formal emergence of a deterrence framework for punishment is often identified with the writings of Cesare Beccaria, an eighteenth-century criminologist and jurist. In his writings on the control and prevention of crime, Beccaria elaborated the general proposition that human behavior can be influenced by variations in punishments. ${ }^{29}$ The origins of deterrence theory in fact are traceable to the centuries preceding Beccaria's essays, when the death penalty was imposed often and for many offenses, some of them quite trivial. ${ }^{30}$ Prior to this, popular sentiment regarded the fate of those executed as deserved and morally unproblematic. Deterrence theory emerged when societies for the first time felt obliged to provide rational justifications for using the death penalty while rejecting other forms of judicial violence such as trial by torture, stoning, and the like.

29 See Michel Foucault, Discipline and PunISH: The BIRTH OF THE Prison (Alan Sheridan trans., Vintage Books 2d ed. 1995) (1977); DAVID GARLAND, PUNISHMENT AND MODERN SOCIETY 208 (1990); Franklin E. Zimring \& Gordon J. HaWkins, DETERrEnCE 75 (1973).

30 Dane ARCher \& Rosemary Gartner, VIOLEnCE and Crime in Cross-National PERSPECTIVE 118 (1984). 
Although deterrence theory may conceal other ancient themes of punishment, especially retribution, its utilitarian justification lies in the notion of crime control. $^{31}$ Briefly stated, deterrence theory holds that there is an effective relationship between specific qualities of punishment (for example, its certainty or severity), and the likelihood that a punishable offense will be committed. According to these ideas, increasing the penalty for an offense will decrease its frequency because deterrence theory conceives potential criminals as rational, econometrically grounded actors who weigh the qualities and probabilities of punishment before acting. Such actors would naturally rather avoid punishment and therefore are discouraged from criminal behavior. Importantly, the effectiveness of deterrence is premised on the actor's knowledge of the sanctions themselves and an ability to weigh not only the severity of the sanction with which he or she will be met, but also the likelihood of being met with that sanction. More recent specifications of deterrence elaborate on the rationality of deterrent calculus by incorporating the reward component of crime. ${ }^{32}$ The tension between the risks and rewards of crime reflects what Jeremy Bentham characterized as the "hedonistic calculus" people use in making decisions. ${ }^{33}$

Yet, while the massive increase in American punishment is heavily influenced by deterrence theory, ${ }^{34}$ modern deterrence research has failed to find consistent evidence of the deterrent effects of punishment. Empirical evidence on the

31 As distinguished from other forms of social control, deterrence includes a retributive element, especially punishment in the form of deprivation or pain. See ZIMRING \& HAwKINS, supra note 29, at 33 (agreeing with K.G. Armstrong, The Retributivist Hits Back, in THE PHILOSOPHY OF PUNISHMENT 138, 156 (H.B. Acton ed., 1969); see also Nagin, supra note 12.

32 See, e.g., Jeffrey Fagan \& Alex R. Piquero, Rational Choice and Developmental Influences on Recidivism Among Adolescent Felony Offenders, 4 J. OF EMPIRICAL LEGAL STUD. 715 (2007) (showing that risk and reward both contribute to the decisions to continue in or desist from crime); Bill McCarthy \& John Hagan, When Crime Pays: Capital, Competence, and Criminal Success, 79 SOC. FORCES 1035 (2001) (showing that a heightened desire for wealth, a propensity for risk-taking, a willingness to cooperate, and competence all contribute to both legal and illegal income); Irving Piliavin, Rosemary Gartner, Craig Thornton \& Ross L. Matsueda, Crime, Deterrence and Rational Choice, 51 AM. SoC. REv. 101 (1986) (showing that the reward component of crime competes with sanction risks to explain variations in crime rates). See also Jeffrey Fagan \& Richard B. Freeman, Crime and Work, 25 CRIME \& JUST. 225 (1999) (showing the role of social and monetary rewards as offsets to sanction risks in crime decision making); Ross L. Matsueda, Derek A. Kreager \& David Huizinga, Deterring Delinquents: A Rational Choice Model of Theft and Violence, 71 AM. Soc. REV. 95 (2006) (identifying the tension between crime rewards, sanction risks and sanction costs in explaining desistance from crime among active offenders).

33 JeREMy BENTHAM, AN INTRODUCTION TO THE PRINCIPLES OF MORALS AND LEGISLATION 144 (J. H. Burns \& H.L.A. Hart eds., Claredon Press 1996) (1789).

34 This is not to say that additional factors such as a concern for incapacitation or retribution do not also influence our current punishment practice. These factors also clearly have an important role. The recent rise in "three-strikes" legislation is obviously driven by incapacitation concerns, and there has been a long-standing role for retribution in sentencing. See, e.g., ROGER W. HAINES, JR. WITH JeNNIFER C. WOll \& FranK O. BOWMan, III, Federal SENTENCING GuIDElines HaNdBoOK 3 (1997) (discussing various rationales for sentencing including retribution in the form of "just deserts"). 
deterrent effects of punishment remains speculative and inconclusive, and the ability of formal punishment alone to deter crime appears to be quite limited. ${ }^{35}$ This is hardly surprising if we view punishment and deterrence in the broader framework of social control. The current primacy of legal controls compared to other forms of social control in modern punishment practice contradicts classical thinking on the regulation of social behaviors through normative social processes. ${ }^{36}$

We contend that modern policymakers have lost sight of what classical deterrence theorists have accepted for quite some time. Social control theorists beginning with Durkheim have concurred that social norms are not simply imposed on individuals by societal structures or processes. Rather, they are effective only when internalized through formal and informal processes of socialization, or where formal sanctions are reinforced by informal sanctions. ${ }^{37}$ That is, where specific deterrent effects are based on the internalization of the perceived costs of law violation (that is, punishment costs), informal social controls suggest costs associated with the act itself and both social and material rewards of crime that are set through neighborhood contexts and norms. ${ }^{38}$

Deterrence theorists have long acknowledged a conditional relationship between formal and informal sanctions where formal legal sanctions may initiate societal reactions that complement the legal costs of punishment. ${ }^{39}$ Others suggest that formal sanctions cannot be effective in the absence of informal social sanctions. Both the direct costs to the offender of legal sanctions (the intrinsic punitive consequences of arrest) and the social costs of legal sanctions are salient as controls, although the effects of legal sanctions seem to be indirect and work through their facilitation of informal social controls. The relationship between formal and informal sanctions also may be seen as additive-where both sources

35 See, e.g., DETERRENCE AND INCAPACTTATION: Estimating THE EFFECTS OF CRIMINAL SANCTIONS ON CRIME RATES (Alfred Blumstein, Jacqueline Cohen \& Daniel Nagin eds., 1978); Philip J. Cook, Research in Criminal Deterrence: Laying the Groundwork for the Second Decade, 2 CRIME \& JUST. 211 (1980); Lawrence W. Sherman \& Douglas A. Smith with Janell D. Schmidt \& Dennis P. Rogan, Crime, Punishment, and Stake in Conformity: Legal and Informal Control of Domestic Violence, 57 AM. SOC. REV. 680 (1992).

36 See, e.g., Charles R. Tittle \& Charles H. Logan, Sanctions and Deviance: Evidence and Remaining Questions, 7 LAW \& SOC'Y REV. 371 (1973); SOCLAL CONTROL: VIEWS From THE SOCIAL SCIENCES (Jack P. Gibbs ed., 1982); ZIMRING \& HAWKINS, supra note 29.

37 Lewis A. Coser, Presidential Address: Two Methods in Search of a Substance, 40 AM. Soc. Rev. 691 (1975); Harold G. Grasmick \& Robert J. Bursik, Jr., Conscience, Significant Others, and Rational Choice: Extending the Deterrence Model, 24 LAW \& Soc'y REV. 837 (1990); Piliavin et al., supra note 32; Tittle \& Logan, supra note 36. See generally Jeffrey Fagan \& Deanna L. Wilkinson, Social Contexts and Functions of Adolescent Violence, in VIOLENCE IN AMERICAN SCHOOLS 55 (Delbert S. Elliott, Beatrix A. Hamburg \& Kirk R. Williams eds., 1998).

38 See Kirk R. Williams \& Richard Hawkins, Wife Assault, Costs of Arrest, and the Deterrence Process, 29 J. RES. CRIME \& DELINQ. 292 (1992) [hereinafter Williams \& Hawkins, Wife Assault].

39 Id. See also ZIMRING \& HAWKINS, supra note 29. 
of sanctions combine to deter offenders-or as replacement-where legal controls replace the effects of social sanctions or controls. ${ }^{40}$

Informal social controls that are facilitated by legal sanctions create a coercive context where social costs are made more salient. But informal controls that rely on contextualized social processes involve more than the interactions between victims, offenders and the interventions of legal institutions. Social control involves the normative processes and ethics of social interaction that regulate everyday social life, as well as the mobilization of community that occurs in response to problem behaviors. ${ }^{41}$ Thus, informal social controls are effective in several ways: inhibition of problem behaviors, facilitation of conformity, and restraint of social deviance once it appears.

Informal social controls are facilitated and perhaps made more salient by the reciprocity between legal and social controls. Kirk Williams and Richard Hawkins suggest that community knowledge of an individual's probable involvement in a violent act is necessary for the activation of informal social controls. ${ }^{42}$ Such knowledge may accrue either from a formal intervention (arrest) or from information networks independent of the formal sanctioning agents. These informal, often interpersonal, social controls often involve explicit or remedial actions to raise the social costs of crime. Williams and Hawkins identify three types of informal controls and social costs that may interact with formal (legal) sanctions: social disclosure (commitment costs), relationship costs (attachment costs), and shame (stigma costs). In other words, the effectiveness of these controls requires that an offender perceive that his social ties and accomplishments will be jeopardized by his actions. ${ }^{43}$ These social costs covary with the person's "stakes in conformity": persons with community ties including marriage and employment are more likely to perceive higher social costs should their illegal behavior be disclosed. ${ }^{44}$ This means that social ties are weakened or are more difficult to establish in neighborhoods with low marriage rates and high unemployment.

Each of these social costs reflects the social structure of the neighborhood context where offenders live or work. Commitment costs include the possible loss of employment chances, educational opportunities, and integration in other social

40 Grasmick \& Bursik, supra note 37.

41 Daniel P. Doyle \& David F. Luckenbill, Mobilizing Law in Response to Collective Problems: A Test of Black's Theory of Law, 25 LAW \& SOC'Y REV. 103 (1991).

42 Williams \& Hawkins, Wife Assault, supra note 38, at 305 (showing that the social and personal costs of violence are greater when there is social disclosure to neighbors or co-workers of an individual's violent behavior).

43 Id. at 306.

44 See Jackson Toby, Social Disorganization and Stake in Conformity: Complementary Factors in the Predatory Behavior of Hoodlums, 48 J. CRIM. L. Criminology \& Police SCI. 12 (1957). 
contexts such as church or a peer group. ${ }^{45}$ Attachment costs include the loss of valued friendships as well as marriage prospects or cohabitational partners. Stigma is associated with social opprobria and damage to one's reputation from social disclosure of criminal status. Social cohesion among neighbors, social capital that regulates behavioral norms across generations, residential mobility, and general crime and violence rates in neighborhoods will influence the stigma attached to disclosure of crime. ${ }^{46}$

These informal controls are likely to be effective under fairly specific social conditions. The perceived (social) costs of violence depends on the salience of these costs to the individual, and the salience depends in part on the individual's liability to (or "stake" in) the community. If the costs are minimal, however, the effects of informal controls or formal sanctions will be weak. ${ }^{47}$ Thus, the material costs of sanctions and the social censure attached to them will directly influence the effectiveness of social controls. ${ }^{48}$ These material factors and the social networks in which offenders are embedded will reflect the social structure and social cohesion of their immediate social contexts.

Accordingly, the disparate findings on the deterrent effects of legal sanctions may reflect the covariation and reciprocity between formal and informal sources of social control that produce deterrence. Both general and specific deterrence conceptions suggest that individuals will commit fewer crimes if they perceive that the benefits of compliance outweigh the punishment costs of legal sanctions and the salience of these benefits depend on the individual's access to societal rewards, as well as the premium the person associates with those rewards. The availability of these rewards varies across communities, reflecting variation in local labor markets and other economic conditions. Legal punishments interact with both an offender's human capital and with the social context of his or her daily interactions, to produce or compromise deterrent effects. ${ }^{49}$

Both general and specific deterrence should be influenced by the social and economic context in which individuals weigh the costs of punishment and the

45 Kirk R. Williams \& Richard Hawkins, Perceptual Research on General Deterrence: A Critical Review, 20 LAW \& SOC'Y REv. 545, 565 (1986) [hereinafter Williams \& Hawkins, Perceptual Research].

46 James S. Coleman, Foundations of Soclal THEORY (1990); James S. Coleman, Social Capital in the Creation of Human Capital, 94 AM. J. SoC. S95 (1988) [hereinafter Social Capital]; Robert J. Sampson \& W. Byron Groves, Community Structure and Crime: Testing SocialDisorganization Theory, 94 AM. J. SoC. 774 (1989).

47 Williams \& Hawkins, Perceptual Research, supra note 45, at 566.

48 Daniel S. Nagin \& Raymond Paternoster, Enduring Individual Differences and Rational Choice Theories of Crime, 27 LAw \& SoC'Y REV. 467 (1993) [hereinafter Nagin \& Paternoster, Enduring Individual Differences]; Daniel S. Nagin \& Raymond Paternoster, Personal Capital and Social Control: The Deterrence Implications of a Theory of Individual Differences in Criminal Offending, 32 CRIMINology 581 (1994) [hereinafter Nagin \& Paternoster, Personal Capital].

49 Human capital includes educational attainment, job skills and experience, and other personal attributes that translate into making an individual a valuable and desired commodity in a labor market. 
benefits of continued crime participation or law compliance. These costs have both social and economic dimensions. The material rewards of compliance are likely to vary with labor market conditions generally and with specific individuals' positions within either the licit or illicit labor markets. ${ }^{50}$

Thus, understanding the deterrent effects of punishment requires not only recognition of the dimensions of legal punishment, but also whether legal punishment is a threat worth avoiding: that there is a job with economic and social value to lose, that relationships are stable and have value, and that the assailant is socially embedded in a neighborhood or work context that accords status or metes out shame and social opprobria. Toby referred to an individual's "stake in conformity" to predict the effects of legal sanctions on criminality. ${ }^{51}$ Thus, the material costs of sanctions and the social censure attached to them will directly influence the effectiveness of social controls. ${ }^{52}$ These material factors and the social networks in which people are embedded will reflect the social structure and social cohesion of their immediate social contexts. To the extent that social costs concurrently reflect an individual's social bonds within a neighborhood or stakes in conformity, and long-term labor market prospects available within the city or region, the deterrent effects of social controls are likely to reflect both the individual's social class, human capital and the neighborhood's opportunity structure and social organization.

\section{DETERRENCE AND THE STRUCTURAL CONTEXTS OF PUNISHMENT}

There is a consensus in the literature on concentrated poverty that rapid changes in social and economic structure in the late twentieth century disrupted informal social regulatory processes. ${ }^{53}$ This perspective has been applied not only to crime, but also to a variety of social ills such as teenage pregnancy, family disruption and violence, and school dropout. ${ }^{54}$ As we will demonstrate below,

so Jeffrey Fagan, Drug Selling and Licit Income in Distressed Neighborhoods: The Economic Lives of Street-Level Drug Users and Dealers, in Drugs, CRIME, AND SoCIAL IsOlation 99 (Adele V. Harrell \& George E. Peterson eds., 1992).

51 Toby, supra note 44, at 16-17.

52 Nagin \& Paternoster, Enduring Individual Differences, supra note 48.

53 For summaries on neighborhood social change and crime, see ROBERT J. BURSIK, JR. \& Harold G. Grasmick, NeighborhoOds and Crime (1993); James F. Short, JR., Poverty, ETHNICITY, AND VIOLENT CRIME (1997); Robert J. Sampson \& Janet L. Lauritsen, Violent Victimization and Offending: Individual-, Situational-, and Community-Level Risk Factors, in 3 UNDERSTANDING AND PREVENTING VIOLENCE 1 (Albert J. Reiss, Jr. \& Jeffrey A. Roth eds., 1994); Jeffrey Fagan, Crime and Neighborhood Change, in UNDERSTANDING CRIME TRENDS 81 (Arthur S. Goldberger \& Richard Rosenfeld eds., 2008).

54 Jeanne Brooks-Gunn, Greg J. Duncan, Pamela Kato Klebanov \& Naomi Sealand, Do Neighborhoods Influence Child and Adolescent Development?, 99 AM. J. Soc. 353 (1993) (showing the effects of neighborhood socio-economic status on teenage pregnancy and school dropout after controlling for individual differences in personality and family structure); Jonathan Crane, The Epidemic Theory of Ghettos and Neighborhood Effects on Dropping Out and Teenage Childbearing, 
social structure and context reduce the likelihood that formal punishments based on a cost-only deterrence model will be effective.

\section{A. Community Social Organization}

For most of this century, criminologists have acknowledged the importance of community in explaining crime rates and activating processes of social control. Studying communities in Chicago in the 1920s, Clifford Shaw and Henry McKay noted the persistence of elevated crime rates in certain neighborhoods, regardless of who lived in those areas. ${ }^{55}$ These were areas of the city near the downtown business zones, but lacking in residential stability and wealth and generally with poor quality housing stock. These areas also were traversed daily by people going from outlying residential areas to job sites either downtown or in the industrial areas ringing the central city. In a parallel study of street gangs in 1927, Frederick Thrasher found concentrations of street gangs in many of the same areas, areas that he called "interstitial zones." ${ }^{.56}$ Again, these patterns persisted without a racial concentration. Indeed, Thrasher noted the common dynamics of neighborhood, crime and gang among German, Czech, Jewish, Polish, Italian, African-American, and other ethnic groups. ${ }^{57}$

This research was replicated and extended in several directions in the ensuing decades. A rich sequence of field studies, many focused on streetcorner life in poor communities, examined the interaction of persons and places that produced the types of social instability that often ignited into crime. ${ }^{58}$ Several gang studies, especially the work of Short and Strodtbeck in Chicago and Cloward and Ohlin in New York, showed how the lives of adolescents in gangs were closely linked to the structure of opportunities and efficacy of informal social controls in their neighborhoods. ${ }^{59}$ In Code of the Street, Elijah Anderson further describes how the temptations of respect and status that one can garner by joining street gangs in urban neighborhoods can supplant any lessons from families or teachers about the

96 AM. J. Soc. 1226 (1991) (showing the spread of school dropout and teenage childbirth from one neighborhood to the next as neighborhood conditions worsen socially and economically); see also WILlIaM JulIuS WILSON, WHEN WORK DisapPEARS: THE WORLD Of THE NEW URBan POOR (1996).

55 Clifford R. Shaw \& Henry D. MCKay, JuvenIle Delinquency and URban AREas 1742 (1942).

56 Frederic M. Thrasher, The Gang: A Study of 1,313 Gangs in Chicago 22 (1927).

57 Id. at 5-25.

58 See, e.g., Richard A. Cloward \& Lloyd E. OHLIN, DELINQUENCY AND OPPoRTunity (1960); Albert K. COHEN, DelinQuent Boys (1955); Elliot Liebow, TAlly's CORNER (1967); JAMES F. ShORT, JR. \& Fred L. STRODTBECK, Group PROCESS AND GANG DElinQuenCY (1965); Gerald D. SUTTLES, THE SOCIAL ORDER OF THE SLUM (1968); BeTtYLOU VALENTINE, HuSTLING AND OTHER Hard WORK (1978); WILLIAM FOOTE WhyTE, STREET CORNER SOCIETY (1943).

59 See ClowARD \& OHLIN supra note 58; SHORT \& STRODTBECK, supra note 58. 
importance of maintaining "decent" values. ${ }^{60}$ Recent studies showed the effects of economic restructuring in cities on gangs and youth violence. ${ }^{61}$ Ethnicity and community were themes of studies focusing on delinquency in Hispanic ${ }^{62}$ and Asian $^{63}$ communities.

These studies support the argument that often the social structure of a neighborhood provides a better explanation of high crime rates associated with a neighborhood than do the individual-level demographic characteristics of offenders. This theory of social organization claims that individual-level factors often correlated with crime-such as low economic status or unemployment-do not themselves directly impact crime. Instead, the impact on crime of such factors are mediated by community-level structures, such as friendship networks, participation in formal organizations like PTAs and churches, and supervision of neighborhood teen peer groups. Put another way, the structure of the community in which an individual lives interacts in important ways to either facilitate or retard that individual's criminal or delinquent behavior.

The premise of social organization theory is that differentially organized communities will be able to implement varying levels of social control over residents. Accordingly, "community social organization" is currently defined as the extent to which residents of a neighborhood are able to maintain effective social control and realize their common values. ${ }^{64}$ Community social organization directed toward crime control can protect even poor neighborhoods from crime problems, while communities that are not organized for such control will be more likely to have crime problems. ${ }^{65}$

There are three major dimensions of structural neighborhood social organization: (i) the prevalence, strength, and interdependence of social networks; (ii) the extent of collective supervision that the residents direct, and the personal responsibility they assume, in addressing neighborhood problems; and (iii) the level of resident participation in formal and informal organization such as

60 Eluah ANDERson, Code of the STREet: DeCEnCy, Violence, AND the Moral LifE of THE INNER CITY 102 (1999) [hereinafter ANDERSON, CODE OF THE STREET].

61 John Hagedorn with Perry Macon, People and folks: Gangs, Crime and the Underclass IN A Rustbelt City (2d ed.1998) [hereinafter Hagedorn, PEOPLE and Folks]; Jay MACLEOD, AIN'T No MAKIN' IT: ASPIRATIONS AND ATTAINMENT IN A LOW-INCOME NEIGHBORHOOD (1987); Mercer L. Sullivan, "GetTING PAID": Youth CRIME AND WORK IN THE INNER CITY (1989); CARL S. TAYLOR, DANGEROUS SOCIETY (1989).

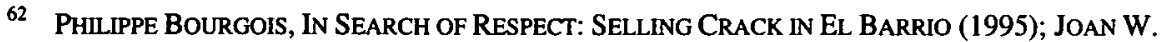
Moore et al., Homeboys (1978); Felix M. Padilla, The Gang as an AMERICAN ENTERPrise (1992); JAMES DIEGO VIGIL, BARRIO GANGS (1988); LUIS J. RODRIGUEZ, ALWAYS RUNNING: LA VIDA LOCA: GANG DAYS IN L.A. (1993).

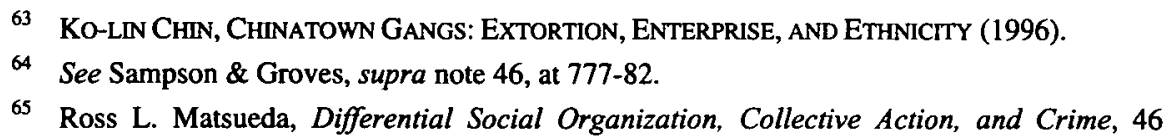
Crime L. Soc. Change 3 (2006); Robert J. Sampson, Stephen W. Raudenbush \& Felton Earls, Neighborhoods and Violent Crime: A Multilevel Study of Collective Efficacy, 277 SCI. 918 (1997). 
churches, block clubs, and PTAs. ${ }^{66}$ By focusing on mediating community social processes such as the level of supervision of teenage peer groups, the prevalence of friendship networks, and the level of residential participation in formal organizations, social organization theory helps to explain the link often noted between individual-level factors, such as race or socioeconomic status, and crime.

The conditions that characterize poor, minority, inner-city communities fit into the social organization model of crime. In urban areas, many poor people of color live in conditions of concentrated poverty and unemployment that predict the breakdown of community social processes, which in turn produce crime. Unlike other poor Americans, African Americans who are poor often live in poor communities. The overwhelmingly poor communities in which many poor African Americans live are marked by unemployment, family disruption, and residential instability. ${ }^{67}$ Non-African Americans who are poor and live in urban areas are unlikely to reside in such desolate conditions. ${ }^{68}$

This means that poor individuals from different urban communities face different challenges. In Shaw and McKay's terms, these challenges include family disruption and urbanization, in addition to low economic status, ethnic heterogeneity, and residential mobility. ${ }^{69}$ Whether social control is effective depends quite directly on the socio-economic factors that set the various costs attached to informal controls. Employment rates and the social organization of work will determine whether the possibility of lost employment and education opportunities are salient commitment costs. Where labor force participation and wages are low, especially among younger non-white males whose offending rates are highest, commitment costs are likely to be relatively low. Marriage and divorce rates, as well as norms of parenting, will influence the social structure of supervision and neighborhood cohesion, as well as the value and meaning of intimate relationships, and in turn establish the attachment costs. Attachment costs will be low in neighborhood contexts where family life is seen as temporary or impermanent, where attachments of male parents to children are weak, and where social networks disproportionately involve poor people and are weakened by residential mobility. Social cohesion among neighbors, social capital that regulates behavioral norms across generations, residential mobility, and general crime and violence rates in neighborhoods will influence the stigma attached to disclosure of crime.

66 See BursiK \& GraSMICK, supra note 53; Sampson et al., supra note 65.

67 Some black middle-class neighborhoods have poverty, crime, schooling, and government services issues that more closely resemble poor ghettos than middle-class neighborhoods. See MARY Pattlllo-McCoy, Black Picket Fences: Privilege and Peril among the Black Middle Class 3 (1999).

68 See Robert J. Sampson \& William Julius Wilson, Toward a Theory of Race, Crime, and Urban Inequality, in CRIME AND INEQUALITY 37 (John Hagan \& Ruth D. Peterson eds., 1995).

69 See SHAW \& MCKAY, supra note 55, at 318-22. 
Moreover, breakdowns in "community social organization" compromise the extent to which residents in neighborhoods of concentrated poverty are able to maintain effective social control through the realization of common values. That is, conditions of structural poverty strain a community's ability to develop informal social controls. Socially organized or cohesive communities are better able to engage in informal social control that can lead to lower levels of crime than communities that are not cohesive. But cohesive communities are able to do so because such communities are able to realize common values, which can be continually reinforced in daily community life through conduct and discourse that center on law abidingness. Such a community can be considered culturally organized. A community's inability to settle on common values is an indicator of less organization. Recent urban ethnography helps to make this point.

In his book, Streetwise, sociologist Elijah Anderson describes in great detail the clash between "decent" values (norms associated with hard work, family life, the church, and law-abiding behavior) held by some families in the urban community that Anderson calls "Northton" and "streetwise" values (norms associated with drug culture, unemployment, little family responsibility, and crime) held by others. ${ }^{70}$ Anderson explains that the diffusion of norms in Northton was correlated with a weakening in Northton's community-level structures. Anderson's research reveals that neither streetwise values nor decent values held sway in Northton, and it is this conclusion that is important for the point we want to make here. Though many of Northton's residents continued to adhere to decent values, even as the structural factors that typically predict community cohesion began to weaken, these residents did so in a world where they were forced to negotiate simultaneously a significant and rival set of values-the streetwise code of conduct-in their daily lives. Competition between streetwise and decent values made it more difficult for law-abiding Northton residents to achieve and reinforce a common set of values among all residents in the community. Furthermore, just as most communities seek to impose a norm of law-abiding behavior, urban neighborhoods have their own set of rules to discourage disrespecting the community; "street-oriented people can be said at times to mount a policing effort to keep their decent counterparts from 'selling out' or 'acting white.' "71 The competition between street and decent values, in addition to making success and survival difficult for many residents, precludes the development of institutions and values that promote norm-compliant behavior.

Even in middle-class African-American neighborhoods, inculcating lawabiding values can prove difficult because of the intermingling of legal and illegal elements of the community. For instance, a study of Groveland, an AfricanAmerican middle-class neighborhood in Chicago's South Side, demonstrates that longstanding community ties and relationships engender sympathy among law-

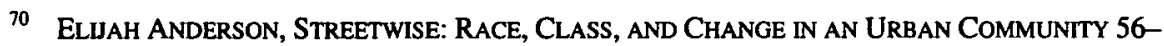
76 (1990) [hereinafter ANDERSON, STREETWISE].

71 ANDERSON, CODE OF THE STREET, supra note 60, at 65. 
abiding people for friends and neighbors on the other side of the law. Indeed, a gang leader who lives in the area promotes social control: a former supervisor at the local park discussed how gang members provided security during a neighborhood event there, and "they were better than the police.", M2 More generally, the presence of a gang has "translated into fewer visible signs of disorder, less violence, and more social control" because of the alignment of interests of the gang leaders and upstanding citizens in the community in keeping Groveland stable and safe. ${ }^{73}$

So one way to assess cultural organization in a community is by looking to the diversity or fragmentation of community values and norms that are likely to flow from weak community organizational structures. Both structural organization and cultural organization in neighborhoods help to explain the crime that occurs in them. They are critically intertwined. Structural organization of neighborhoods is like a system of "norm highways." The condition of this infrastructure will either facilitate or hinder the transmission of community values that can support lawabiding behavior.

Several factors operate to either facilitate or inhibit communities in their quest for engagement in social control. Three are emphasized here in the subsections that follow: the relevance of communities of liability to the potential offender; the social meaning and nature of work in the would-be offender's neighborhood; and the nature and norms of family relationship in the individual's offender's community.

\section{B. Communities of Limited Liability}

The notion of a community of limited liability was advanced by Morris Janowitz. $^{74}$ According to Janowitz, people living in an area have psychological attachments to, and social investments in, that area. ${ }^{75}$ The extent and character of these attachments reflect an individual's view of community, and their social position in the community. So, raising a family, attending school, and local social contacts predispose individuals to accept the normative orientation of local community institutions and social controls. In simpler times, the intersection of social, economic, and religious life within one community made such liability quite broad. It also created a mutuality where investments of time and acceptance of cultural norms were recognized and rewarded with social standing and, in some cases, assets useful in work and business. Variation in social class and status result in variations in involvement in social control processes.

72 Mary E. Pattillo, Sweet Mothers and Gangbangers: Managing Crime in a Black MiddleClass Neighborhood, 76 SOC. ForCEs 747, 757 (1998).

73

Id. at 767.

74 Morris Janowitz, Sociological Theory and Social Control, 81 AM. J. SoC. 82 (1975).

75

MORRIS JANOWITZ, ON SOCIAL ORgANIZATION AND SOCLAL CONTROL 256-69 (1991). 
"Liability" in this context is limited when individuals demand more from their community than they receive, and they then withdraw in part or whole from the normative structure of the community when that demand is not fully met. Thus, failing to achieve social standing, economic return, or simply a level of service, may limit participation in the regulatory processes of community life that comprise social control. This may involve withdrawal from the social organization of the community, or simply from primary group contacts. Whatever the withdrawal, the sum of this process across individuals implies a lessening of social controls in the community. The result is that most people have varying levels of involvement in social control, with a few people unaffected and some deeply involved in the active processes of control.

Structural changes have attenuated liability in several ways, and increased the fragmentation of community attachments and participation. In fact, the social organization of everyday life is quite different today compared to the earlier times when social control theorists formulated their ideas. For example, patterns of work among family members involve greater amounts of time out of the home and, in the case of families with two parents working outside the home, often no adult in the home. Travel to and from work and other routine activities also involve greater amounts of time in cars and otherwise away from home. When no adult in the home has a primary attachment to the residential community, liability is very narrow and immersion of household members in networks of social control is minimal.

School busing in many areas disrupts the types of within-neighborhood attachments that were the foundation of the "functional communities" described by Coleman and Hoffer, and also attenuates the interlocking social networks fostered by teacher-parent-student-employer relationships that form a community's social capital. $^{76}$ In People and Folks, John Hagedorn describes how school busing attenuated attachments of local youths to their communities, weakened community controls over schools, and made more efficient efforts by gang members to recruit young students whose attachment to school and community was attenuated by their lengthy trips to schools that were far from the locus of the students' sources of social control. ${ }^{77}$ These trends contribute to a series of limited or disconnected liabilities for both adults and children in residential communities, and a weakening of social controls.

Modern social structural changes exert a strong pull that weakens attachments to community, reducing liability and decreasing the salience of social controls. These patterns lessen attachments to residential place, and spread liability across several sectors with varying degrees of "connectedness" to the larger society. To the extent that liabilities are consistently high across communities and other primary group contacts, and these contacts are well-linked to the larger society,

76 See James S. Coleman \& Thomas Hoffer, Public and Private High Schools: The IMPACT OF COMMUNITIES (1987); Coleman, Social Capital, supra note 46.

77 HAGEDORN, PEOPLE AND FOLKS, supra note 61. 
social controls remain functional and strong. But when attachments and liabilities are fragmented, or linked to communities that are detached from larger societal structures, social controls are unlikely to be effective.

\section{The Social Meaning and Economic Structure of Work}

Work performs several functions with respect to social control and reciprocity with punishment. Work itself is a context of social control that regulates behaviors. Or, in the language of the preceding discussion, it provides a community of liability linked to the larger community in which individuals are embedded. Work also has intrinsic rewards through social status in small group interactions, building attachments and making more salient the social dimensions of punishment "cost." In fact, positive work outcomes have proven to be quite important in changing behavioral patterns across developmental stages. ${ }^{78}$ An econometric, rational choice perspective on crime and work suggests that individuals will allocate time to criminal behavior when its returns are higher than other activities, net of perceived punishment costs and estimates of foregone illegal wages. That is, decisions to engage in crime suggest that offenders find the current net benefits of crime to be positive, especially relative to punishment costs. Not only do labor market variables account for an individual's assessment, but factors including tastes and tolerances for risk, preferences for work, and time allocation also are part of the decision processes.

Work has changed in many important ways that undermine its functions for social control, particularly for individuals who have experienced punishment. A sustained decline in wages for unskilled workers has weakened both attachments to work and incentives to participate. ${ }^{79}$ More importantly, the returns from illegal work often exceed legal wages for workers with limited human capital or access to higher wage jobs, and neutralize incentives to avoid crime and possible punishment. ${ }^{80}$ The attractions of illegal work are reflected in variables often unmeasured in quantitative studies on crime and work, especially "tastes and preferences" that inflate the nonmonetary dimensions of illegal work. ${ }^{81}$

This is an extremely important part of the paradox of imprisonment: throughout the 1980s, illegal wages increased while legal wages declined for individuals at the social position of most incarcerated offenders. ${ }^{82}$ People with

78 Robert J. Sampson \& John H. Laub, Crime in the Making: Pathways and Turning POINTS THROUGH LIFE (1993).

79 See WESTERN, supra note 5; Fagan \& Freeman, supra note 32.

80 See Fagan \& Freeman, supra note 32.

81 Jeff Grogger, Market Wages and Youth Crime, 16 J. LAB. Econ. 756 (1998); Sudhir Alladi Venkatesh, The Social Organization of Street Gang Activity in an Urban Ghetto, 103 AM. J. Soc. 82 (1997); W. Kip Viscusi, The Risks and Rewards of Criminal Activity: A Comprehensive Test of Criminal Deterrence, 4 J. LAB. ECON. 317 (1986).

82 Fagan \& Freeman, supra note 32; Viscusi, supra note 81. 
higher illegal incomes did not possess characteristics conducive to success in legal labor markets. With punishment becoming socially normative for potential offenders, punishment costs no longer are contingent and therefore can only weakly function as a discount on legal wages. And, increasing illegal wages create an opportunity cost to the decision to engage in legal work: the cost of foregone illegal wages compete very well with whatever minimal returns could be expected from legal work.

Crime, especially drug selling, provides economic incentives for young innercity males that raise income prospects in ways that legal markets cannot. Workers in the illegal economy either are detached from legal work or have been excluded as a result of the accumulation of legal sanctions. Moreover, their greater involvement with gangs, organized drug selling, and other illegal activities suggests their social embeddedness in contexts that close them off from conventional opportunities. In samples of both drug dealers and general adolescent populations, illegal and total incomes seem to be highest among those who are most active criminally, and these differed systematically from others with far lower criminal involvement. Thus, once involved in illegal work, the incentives to avoid punishment by foregoing legal wages are very weak.

Recent ethnographic work illustrates how the abandonment of legal work has been accompanied by shifts in conceptions of work among young men and women in poor areas. Elijah Anderson describes how young males in inner-city Philadelphia regard the drug economy as a primary source of employment, and how their delinquent street networks are their primary sources of status and social control. $^{83}$ Participants in the illegal economies in inner cities were engaged in a variety of income-producing crimes, including drug selling, fencing, auto theft, petty theft and fraud, commercial extortion, and residential and commercial burglary. In diverse ethnic communities in cities far apart, young men use the language of work ("getting paid," "going to work") to describe their crimes. "In fact, the oppositional culture has ironically dubbed opting to sell drugs as 'getting legal"."85

The confounding of the language of illegal and legal worlds of making money seems to signal a basic shift in the social definition of work. For the young men using this language, money from crime is a means to commodities that offer instrumental value as symbols of wealth and status. Social and economic isolation, resulting from concentrated poverty and segregation, gave rise to a skewed emphasis on exaggerated displays of material wealth as a source of status.

83 See ANDERSON, CODE OF THE STREET, supra note 60; see also MARTIN SANCHEZ JANKOWSKI, ISLANDS IN THE STREET: GANGS AND AMERICAN URBAN SOCIETY (1991); BouRgoIS, supra note 62; CHIN, supra note 63; PADILLA, supra note 62; TAYLOR, supra note 61.

84 TerRy Williams, The Cocaine Kids 87 (1989); Padilla, supra note 62; Sullivan, supra note 61; TAYLOR, supra note 61. For example, Felix Padilla describes how gang members in a Puerto Rican Chicago neighborhood regarded low-level drug sellers in their gang as "working stiffs" who were being exploited by other gang members. PADILLA, supra note 62, at 129-32.

85 ANDERSON, CODE OF THE STREET supra note 60, at 114. 
Anderson describes how motivations for the perceived higher returns from illegal work were influenced by such tastes for quick "crazy" money, and were important components of decisions to engage in illegal work. ${ }^{86}$

Much of this illegal work is organized within ethnic enterprises combining shared economic and cultural interests. For gangs, there is less concern than in the past with neighborhood or the traditional "family" nature of gang life. Gang members with limited exits from gang life remained longer in the gang, assuming leadership roles and manipulating the gang for their own economic advantage through perpetuation of gang culture and ideology ${ }^{87}$ Felix Padilla describes how the new pattern of exploitation of lower-level workers (street drug sellers) in the gang was obscured by appeals by older gang members to gang ideology (honor, loyalty to the gang and the neighborhood, discipline, and ethnic solidarity) combined with the lure of income.

Others also talk about the use of money rather than violence as social control within African-American and Latino drug-selling gangs-if a worker steps out of line, he simply is cut off from the business, a punishment far more salient than threats to physical safety. ${ }^{88}$ Drug-selling groups in these studies superficially are ethnic enterprises but function more substantively as economic units with management structures oriented toward the maintenance of profitability and efficiency. The institutionalization of these sources of illegal work, and their competitiveness with the low status and low income legal jobs left behind after deindustrialization, combine to maintain illegal work careers long after they would have been abandoned in earlier generations.

Patterns of illegal work vary in this literature. Some abandon legal work after a period of employment, others drift in and out of legal work, and a few seem to choose from the outset exclusive "careers" in illegal work. Sanchez Jankowski, for example, claims to have found an "entrepreneurial spirit" as the "driving force in the worldview and behavior of gang members" that pushes them to make rational decisions to engage in the profitable world of drug sales or auto theft. ${ }^{89} \mathrm{McCarthy}$ shows that the human and personal capital that promotes conventional success also promotes criminal success, but the social networks and opportunities available to many inner-city youth with those skills make illegal work a much more obvious and feasible option. ${ }^{90}$ John Hagedorn describes how gang members drift in and out of legal work over time, with decisions closely bundled and often reciprocal. ${ }^{91}$ Hagedorn claims that the illegal-drug labor market vigorously competes with the

86 Id. at 111-12.

87 JOAN MOORE, GOIN' DOWN TO THE BARRIO: HOMEBOYS AND HOMEGIRIS IN CHANGE (1991).

88 TAYLOR, supra note 61.

89 SANCHEZ JANKOWSKI, supra note 83, at 101.

90 McCarthy \& Hagan, supra note 32, at 1038.

91 HAGEDORN, PEOPLE AND FolKs, supra note 61. 
seemingly more "glamorous" opportunities in the legal economy, despite the low wages, low status, dangerous, and often part-time nature of the illegal work. ${ }^{92}$

"Rather than dichotomous choice, economic activity for some people seems to vary over a continuum of legal and illegal 'work'," 93 particularly in inner-city communities. As low wages for unskilled workers reduce opportunity costs of punishment and increased incarceration rates reduce the social stigma of incarceration, the deterrence effects of incarceration abate. ${ }^{94}$ Furthermore, crime wages tend to significantly exceed legal wages. Consistent with a demonstration that illegal wages are relatively elastic, it is apparent that individuals make rational choices between legal and illegal work opportunities, even after adjusting for the risks of law enforcement or violence inherent in criminal behavior. ${ }^{95}$

For others, the hazards and indignity of low wage and low status legal jobs discount the returns from legal work. For example, Bourgois claims that drug dealers who leave legal jobs to embrace the risks and rewards of drug selling are evidence of a culture of resistance, preferring the more dignified workplace of drug selling than the low wages and subtle humiliations of secondary labor markets where racism dominates work conditions and social interactions. ${ }^{96}$

The changes in the structure of employment shape not only job outcomes for young adults, but the outcomes of early legal problems. Sullivan tells how early involvement in crimes was normative in three ethnically diverse neighborhoods, but the outcomes of arrest varied by neighborhoods. ${ }^{97}$ White families helped resolve disputes informally, using family support and job networks to soften the potential stigma of arrest. With high rates of joblessness, non-white families had few social buffers or job networks between them and the legal system. Not only did they lack access to job networks, but their families were of little help when their income-producing crimes (robberies) evoked official responses. Their disrupted job networks were unable to mitigate legal problems or ease the schoolto-work transition, contributing to the continuity of criminality and adverse legal responses.

In contrast, youths in predominantly white neighborhoods were able to make sometimes difficult but successful escapes from adolescent crime networks. Hagan links this to processes of social embeddedness that truncate future options and amplify the adverse effects of adolescent entanglements in the legal system. ${ }^{98}$ Several studies have shown how neighborhoods in the past reproduced their

92 Id. See also ANDERSON, CODE OF THE STREET, supra note 60.

93 Fagan \& Freeman, supra note 32, at 229.

94 Id. at 231.

95 Id. at 230.

96 BoURGOIS, supra note 62.

97 Sullivan, supra note 61, at 199-201.

98 See John Hagan \& Alberto Palloni, The Social Reproduction of a Criminal Class in Working Class London, circa 1950-1980, 96 AM. J. Soc. 265 (1990); McCarthy \& Hagan, supra note 32. 
employment patterns in succeeding generations through networks of job referrals. Today, what is reproduced is joblessness. ${ }^{99}$

\section{The Devaluation of Family}

In deterrence and crime control research, the structure of family life consistently ranks among the most salient forms of informal social control. For example, in a study of robbery rates in 150 U.S. cities, Robert Sampson showed that marriage and divorce rates were the strongest predictors, together with unemployment rates, of arrests for robbery among non-white males. ${ }^{100}$ Longitudinal studies also reaffirm the importance of family as a transitional social role that provides exits from criminality during the developmental transition from adolescence to adulthood. ${ }^{101}$ The elevated risk of domestic violence in central cities has been attributed to social isolation, concentrated poverty, and other structural dynamics that also contribute to violence outside the home in the same areas. ${ }^{102}$ Research on child maltreatment also suggests that there are ecological concentrations of child abuse that reflect social structure. Variations in child abuse rates have been traced to variations in community structure including poverty, residential mobility, and single-parent households. These patterns of social disorganization often are concentrated in urban areas and are also associated with high rates of stranger violence. ${ }^{103}$

Yet structure alone is insufficient to explain variations in betweenneighborhood rates of crime. Within-race, within-income, and within-city variations in family violence, for example, suggest that the effects of structural and ecological factors on child abuse and other forms of intrafamily violence are conditioned by neighborhood processes. James Garbarino and Deborah Sherman compared two neighborhoods matched on socioeconomic and demographic

99 See William Julius Wilson, Studying Inner-City Social Dislocations: The Challenge of Public Agenda Research, 56 AM. SoC. Rev. 1 (1991); Marta Tienda, Poor People and Poor Places: Deciphering Neighborhood Effects on Poverty Outcomes, in MACRO-MICRO LINKAGES IN SOCIOLOGY 244 (Joan Huber ed., 1991).

100 See Robert J. Sampson, Urban Black Violence: The Effect of Male Joblessness and Family Disruption, 93 AM. J. SoC. 348 (1987).

101 See SAMPSON \& LAUB, supra note 78.

102 See Jeffrey Fagan, Social Structure and Spouse Assault, in THE SOCIO-ECONOMICS OF CRIME AND JustiCE 209 (Brian Forst ed., 1993).

103 See Claudia J. Coulton et al., Community Level Factors and Child Maltreatment Rates, 66 ChILD Dev. 1262 (1995); James Garbarino, A Preliminary Study of Some Ecological Correlates of Child Abuse: The Impact of Socioeconomic Stress on Mothers, 47 CHID DEv. 178 (1976); James Garbarino \& Ann Crouter, Defining the Community Context for Parent-Child Relations: The Correlates of Child Maltreatment, 49 CHIID DEv. 604 (1978); Susan J. Zuravin, The Ecology of Child Abuse and Neglect: Review of the Literature and Presentation of Data, 4 VIOLENCE \& VICTIMS 101 (1989). 
characteristics but that varied dramatically on the rates of child maltreatment. ${ }^{104}$ Through interviews with families and neighborhood informants, they identified neighborhood risk factors for child abuse that reflected the urban social context of these neighborhoods rather than their socioeconomic status. These risk factors included what they termed "social impoverishment," a milieu characterized by family social isolation, insubstantial social networks, and weak social supports among family caretakers. ${ }^{105}$

The implications of these dynamics suggest that family interactions will exert strong influences on social control in socially impoverished neighborhoods. Accordingly, risk factors for several antisocial and problem behaviors seem to converge in central cities: interpersonal violence, child maltreatment, social disorganization (high rates of residential mobility, poverty, divorce or family disruption, and female-headed families with children), and weak social networks leading to social isolation. To the extent that these processes describe what Kasarda and Janowitz call a "systemic" model of social disorganization, they are symptomatic of what more recently has been termed "structural" forms of social disorganization-focusing less on the spatial or even geographic dimensions of community than on the structure of social networks within them. ${ }^{106}$

The interaction of community, family and structure form an ecological dynamic of social control, representing what Anderson calls the interconnected realities born of the difficult social conditions in poor communities. ${ }^{107}$ The dimensions of family relevant for social control include the social networks within which families and individuals are embedded, and the social capital among families within the community.

\section{Social Controls}

The structure and meaning of family life influence both informal and formal social controls. If the social costs of punishment are tied to the threat of relationship loss, then these costs are discounted in neighborhoods with high rates of family disruption and dissolution or with low marriage rates. Marriage itself becomes a less desirable option for both men and women in an economic context where young men are systematically excluded from stable employment and consigned to persistent poverty. ${ }^{108}$ The decline in family-sustaining jobs denies

104 James Garbarino \& Deborah Sherman, High-Risk Neighborhoods and High-Risk Families: The Human Ecology of Child Maltreatment, 51 CHILD DEv. 188 (1980).

105 Id. at 196. They also noted that high-risk families may drift toward high-risk neighborhoods, creating a compositional or aggregation effect. Id.

106 John D. Kasarda \& Morris Janowitz, Community Attachment in Mass Society, 39 AM. SoC. REv. 328, 329 (1974).

107 ANDERSON, STREETWISE, supra note 70, at 112-37.

108 See William Juluus Wilson, The Truly Disadvantaged: The InNer CrTy, the UNDERCLASS, AND PUBLIC POLICY (1987) (discussing the pool of marriageable men). 
many young men in urban areas, especially areas where labor force participation has declined, the opportunity to pursue an economically self-sufficient family.

For young males, the declining interest in marriage as a long-term goal skews male-female relationships and the definition of gender roles regarding manhood. In this political economic context, sexual prowess is one of the few opportunities left to gain and display personal power and accomplishment. ${ }^{109}$ Their exploitation of women, coupled with their weak economic future, make these young men less desirable marriage partners for women, leading to more transient sexual relationships and an increasing prevalence of female-headed families with children. ${ }^{110}$ Ulf Hannerz noted that in considering marriage, "there is an awareness among ghetto dwellers that they may be literally "taking a chance on love." "111 If marriage is a protective factor against criminal participation, then the risks of sustained criminal involvement grow with the decline in marriage tied to the declining economic fortunes of young men.

More generally, social control is also affected by neighborhood dynamics. Stigma costs are low for punished offenders when there is little cohesion among neighbors, or when neighbors know little of each other or feel little responsibility for what happens in their neighborhoods. When liabilities are attenuated, and stakes in the neighborhood are low, there is little inclination among neighbors to directly cast their sanction on the punished offender. Neighbors also have less motivation to intercede personally, to react to crimes generally, or to develop and express social norms against that behavior.

\section{Social Networks and Social Isolation}

The importance of social networks, especially those involving families, in informal social control is illustrated by ethnographic literature on communities. ${ }^{112}$ For example, kinship networks generally are more prevalent among lower social class families as well as non-white families; higher socio-economic status families tend to rely on occupational networks rather than kin-based networks. Among low-income African-American families, these networks depend on regular

109 See generally ANDERSON, STREETwISE supra note 70; GeOFFrey CANADA, Fist, STICK, Knife, Gun (1995); William Oliver, The Violent Social WORLD OF Black Men (1994); KENNETH POLK, WHEN MEN KILL (1994).

110 In this context, women may see young men as burdens or risks rather than as assets in achieving the passage of setting up their own households. ANDERSON, STREETWISE, supra note 70, at 134-37.

111 Ulf HANNERZ, SOULSIDE: INQUIRIES INTO GHETTO CULTURE AND COMMUNITY 71 (1969).

112 See generally ANDERSON, STREetwise, supra note 70; MARY PATTLLO, BLACK ON THE Block: The POlitics of RaCE and Class IN THE CITY (2007); PATtIllo-McCoY, supra note 67; Sudhir Alladi Venkatesh, The Gang in the Community, in GANGS IN AMERICA 241 (C. Ronald Huff ed., 2d ed. 1996). 
interactions among network members, close living arrangements, and shared resources such as child supervision, food, and shelter. ${ }^{113}$

Also, the intricate relationships among natural extended families or ritual kin relations (compadres) is a sociocultural process central to socialization in Puerto Rican neighborhoods. In these networks, the family serves as the cornerstone of the culture, defining and determining individual and social behaviors. Relatives by blood and ceremonial ties, as well as friends of the family, are linked in an intricate network of reciprocal obligations that promote collective sharing of both misfortunes and good times. Among adolescents from families with low income, absent fathers, or troubled family relationships, the value of familism may be invoked by parents or other family members to restrain their involvement in antisocial behavior. ${ }^{114}$ But in middle-class African communities that exhibit cohesive extended-family networks, having numerous adults does not always translate into better supervision or familial control of youth; in situations where grandparents assume a parental role, generational differences that inhibit communication combined with grandparents' limited financial resources and energy levels can limit the exercise of strong controls on youth behavior. ${ }^{115}$

As with other social processes, social isolation affects micro-social (individual) interactions and communities. Residential mobility has far-reaching consequences for disruption of social networks. To the extent that networks are composed of family relationships, the decline in two-parent families in poorer neighborhoods signals a narrowing of the kinship networks that form around marriage and children. Other social networks have become increasingly comprised of people with low incomes or low occupational status in central cities as middle income non-whites and whites have moved away from traditional neighborhoods.

For those left behind, especially non-whites, access to family-sustaining work becomes more difficult and the networks increasingly reflect the behaviors and norms of those marginalized within closed neighborhoods. The risks and motivations for crime increase as the protective networks of kinship weaken within

113 See Claude S. Fischer, To Dwell among Friends: Personal Networks in TOWN AND CITY (1982); CAROL B. STACK, ALL OUR KIN (1974).

114 Familism has been defined as a value system in support of the family which emphasizes the bonds and obligations between relatives and the duty to help and express concern for them. See Lloyd H. Rogler \& Rosemary SANTANa COONEY, PuERTo Rican FamIIIES IN NEW York City: INTERGENERATIONAL PROCESSES (1984). Ties between families are cemented by the establishment of compadrazco (godparent-godchild) relationships. PADILLA, supra note 62. The godparents at baptism or sponsors at confirmations are the padrinos of the child and become co-parents with the natural parents. Witnesses at a wedding become compadres of the married couple. See Joseph P. Fitzpatrick, Drugs and Puerto Ricans in New York City, in DRUGS IN HiSPANIC CoMmUNITIES 103 (Ronald Glick \& Joan Moore eds., 1990). These serious relationships involve reciprocal obligations that often are as demanding as natural family relations. Within this milieu, the well-being of the individual is subordinated to the welfare of the family or kinship network. See also Nancy A. BuschRossnagel \& Luis H. Zayas, Hispanic Adolescents, in ENCYCLOPEDIA OF ADOLESCENCE 492 (Richard M. Lerner, Anne C. Petersen \& Jeanne Brooks-Gunn eds., 1991).

115 PATTILLO-MCCOY, supra note 67, at 74-75. 
central cities. Intimate relationships suffer from the weakening of social networks, the frustration of material deprivations, and behavioral influences from other jobless families in the neighborhood. ${ }^{116}$

Increasing residential segregation and isolation of residents from the social and economic institutions that represent mainstream society weaken the influence of the larger society on interpersonal behaviors. ${ }^{117}$ The absence of more conventional patterns of family interactions, patterns otherwise facilitated by working families embedded in stable kinship or friendship networks, facilitates the transmission and reification of more violent patterns. The rare and skewed contacts of neighborhood residents with people in other social contexts (such as work or commercial transactions) allows norms and attitudes supportive of violence in intimate relationships to prevail over non-violent norms. In turn, young people considering coupling or marriage are more likely to be exposed to violent interactions between adult intimates. Eventually, these norms are internalized as their transmission becomes more efficient. These are the processes that create "cultural disorganization" as a byproduct of social disorganization.

These themes are evident throughout the ethnographic literature on inner-city life going back to the 1930s, which consistently notes the routine incidence of family conflict and disruption within segregated, socially isolated and disorganized communities. $^{118}$ Elliott Liebow, for example, described violent transactions between men and women that often followed struggles over (scarce) money. $\mathrm{He}$ concluded that "the widespread violence between streetcorner husbands and their wives seems to be more a product of persons engaged in an always failing enterprise than merely the 'style' or 'characteristic feature' of streetcorner husband-wife relationships."119

Liebow went on to describe male violence toward spouses that is contextualized in their frustration over failing to meet their wives' legitimate expectations for herself and her children, and a context for "angry aggression" among household members. ${ }^{120}$ Marriage becomes an occasion for failure; the

116 See Sampson \& Wilson, supra note 68.

117 See, e.g., DOUglas S. MASSEY \& NANCY A. DENTON, AMERICAN APARTHEID: SEGREGation AND THE MAKING OF THE UNDERCLASS (1993); DOUGlas S. MASSEY, CATEGORICALLY UNEQUAL: THE AMERICAN STRATIFICATION SYSTEM (2007); Edward S. Shihadeh \& Nicole Flynn, Segregation and Crime: The Effect of Black Social Isolation on the Rates of Black Urban Violence, 74 SOC. FORCES 1325 (1996); David Bjerk, The Effects of Segregation on Crime Rates, (Am. Law \& Econ. Ass'n Annual Meetings, Paper 13, No. 2006), available at http://law.bepress.com/cgi/viewcontent.cgi?article=1693\&context=alea.

118 See Eluah ANderson, A Place on the Corner (2d ed. 2003); ANDERSON, STREetwiSe supra note 70; HANNERZ, supra note 111; OSCAR LEWIS, LA VIDA (1966); LIEBOW, supra note 58; LEe Rainwater, BehIND GHETto Walls: BlaCK FAMILIES IN A FEDERAL Slum (1970); STACK, supra note 113; SUTTLES, supra note 58; WHYTE, supra note 58.

119 LIEBOW, supra note 58 , at 127 n.14.

120 Id. See also Thomas J. Bernard, Angry Aggression Among the "Truly Disadvantaged", 28 Criminology 73 (1990). 
inability to support a family results in losses of self-esteem and social status among neighbors and transfers marital power to the woman. ${ }^{121}$ The tension between maintaining the public image of "breadwinner" and a dominant role in the home on the one hand, and the economic and social problems in achieving that role on the other, create strains within marriages that often lead to violent conflicts and breakup. It also creates a cautiousness in coupling and marriage that fosters a high rate of divorce or dissolution.

Within socially isolated neighborhoods where structural conditions foster marital relations that are transient and frequently conflicted, young people form definitions of marriage or male-female relations that devalue family life. Adolescents and young adults may be more likely to develop norms that work against family life and lower both attachment and commitment costs attached to intimate relationships. When marital instability becomes normatively valuable, the costs of criminal participation attached to family go to zero. To the extent that these processes are shaped by the social structural factors-especially segregation, residential mobility and concentrated poverty - a system of values may emerge regarding expectations of conduct. These may become what Liebow calls a "shadow system of values" that influences socialization and social development. ${ }^{122}$

\section{Social Capital}

The third dimension of family that addresses social control is social capital. James Coleman defines social capital as the structure of relations among people, particularly relations that lead to social action "making possible the achievement of certain ends." 123 It fosters the processes by which behavioral norms are set and regulated and by which they are transmitted from one generation to the next within families and across kinship and social networks. But the idea of social capital requires that these relationships transcend families, and encompass the broader sets of relations between families and across generations, as well as between families and institutional networks: parent-teacher relationships, religious affiliations, and economic relationships that cross generations and legal institutions. ${ }^{124}$

Accordingly, the influences of social capital are greater than any that could occur within a single family or kinship network. And the relationships within a single network or family alone cannot produce social capital. ${ }^{125}$ Deficits in social capital are symptomatic of communities with limited social networks and weak

${ }^{121}$ See LIEBOW, supra note 58 , at $130 \mathrm{n} .16$.

122 Id. at 213.

${ }^{123}$ See Coleman, Social Capital, supra note 46, at $\$ 98$. This is distinguished from human capital that is tangible: skills, resources and knowledge.

124 Id. at S113. See also COLEMAN, supra note 46, at 302-04, 318-20.

125 Robert J. Sampson, Family Management and Child Development: Insights from Social Disorganization Theory, in FACTS, FRAMEWORKS, AND FoRECASTS 63, 81-84 (Joan McCord ed., 1992). 
cohesion among their residents. To the extent that networks are attenuated, they may become ineffective at controlling behaviors and sustaining norms.

Social capital accrues when individual behaviors occur in multiple contexts and are subject to multiple reactions. The young person experiencing marital conflict may encounter reactions from family members, work-related acquaintances, or neighbors. If these relationships exist within fairly dense networks of acquaintances, obligations, and expectations, the reactions (or sanctions) of people within these networks to those experiencing problems will be more consistent and have greater salience.

The extent to which social capital is depleted under conditions of social disorganization and structural deficits should be fairly obvious. ${ }^{126}$ Not only are kinship and economic networks subject to breakup under structural conditions of unemployment, poverty, and residential mobility, but so too do demographics work against the formation of social capital. The concentration of female-headed families with children compromises the effectiveness of cross-family intergenerational relationships.

To some degree, these relationships depend on modeled behaviors based on exposure of young people to adults. The depletion of the "marriage pool" of adult males certainly threatens social capital. The limited contacts between males of younger and older generations in these contexts not only truncates the learning and mentoring relationships that develop but also weakens the informal social controls that regulate the behaviors of young males and females. These relationships teach and reinforce lessons about intimate relationships and coupling. They also provide important gateways for connections to the wider society through jobs, social ties, and friendship networks. And the ability of young males and females to achieve their expectations for intimate relationships and for their individual lives is enhanced through involvement in interlocking networks of commitments and obligations that offer support for child care, job prospects, and rewarding social interactions. Accordingly, the depletion of social capital helps sustain social isolation, promotes cultural disorganization, and weakens informal social control.

\section{THE PARADOXICAL EFFECTS OF FORMAL PUNISHMENT AND SOCIAL ORGANIZATION}

We return, then, to the paradoxical effects of imprisonment in the United States in the late twentieth century. Offending rates increased, rather than decreased, in the face of escalating punishment costs of crime: the tripling of imprisonment rates, the lengthening of sentences, and the reduction of punishment thresholds relative to the severity of crimes. Using a framework of deterrence and

126 But social capital also may fail to accrue even under more benign structural conditions, particularly in neighborhoods marked by infrequent contacts between families or limited crossgenerational and cross-family integration within the contexts of schools or other institutions. 
social control, several factors can be implicated in the declining deterrent effects of punishment.

First, punishment has had unanticipated iatrogenic effects with respect to crime and negative effects on legal work. Several studies have shown that incarceration during adolescence and early adulthood has negative effects on employment and positive effects on crime in later adult years. ${ }^{127}$ Both longitudinal and ethnographic studies place delinquency before unemployment in the sequence of developmental events over the life course. The assignment of a criminal record places concrete and lasting barriers to future employment, and for former inmates, reduces their choices with respect to avoiding crime and entering positive social roles. Increasing rates of incarceration and lower thresholds for imprisonment beginning in the 1980s have attenuated access to legal work that already was complicated by considerations of race, human capital, location, and discrimination.

Second, fundamental changes in the structure of work for marginally employed persons have lowered expected returns from legal work. The deterrent argument for punishment, at its simplest, suggests that the costs of punishment will exceed the returns from illegal work. However, declining wages and job mobility for unskilled workers combine to reduce incentives to avoid punishment, regardless of illegal incomes. ${ }^{128}$

Third, the corollary effect of widespread perceptions of increasing returns from illegal work-crime-undermine deterrence. That is, the costs of crime in foregone legal wages are no longer worth avoiding.

Fourth, punishment costs are discounted by cultural shifts, such as cultures of opposition and defiance of the goals of punishment. ${ }^{129}$ This has occurred in spite of, or perhaps because of, objective increases in their certainty and severity. In fact, the increasing reliance on state-administered rather than informal social controls, contributes to the escalation of defiance and the delegitimization of punishment.

127 See, e.g., Fagan \& Freeman, supra note 32.

128 See, e.g., Hagan \& Palloni, supra note 98 (on the embeddedness of criminal offenders in spatial and social contexts where the perceptions of returns from legal work are overwhelmed by normative perceptions of the limitations and futility of legal work). See also BouRGoIS, supra note 62; ANDERSON, STREETWISE, supra note 70; ANDERSON, CODE OF THE STREET, supra note 60 (on the devaluation of legal but low-wage work).

129 The formation of oppositional cultures has been described by Elijah Anderson. See ANDERSON, CODE OF THE STREET, supra note 60 . The process suggests that the isolation of marginalized communities has skewed perceptions of legal or conventional success so that achievement in school or the legal workplace is identified with an oppressive dominant economic and cultural order. Young people who pursue such success are themselves isolated and denied social standing in street networks in areas of social isolation and concentrated poverty. Defiance of the goals of punishment is part of this culture. See Sherman, supra note 11. Intrinsic emotional rewards from behaviors defying the goals of punishment outweigh whatever material rewards may be forthcoming from compliance and conformity. 
A vicious cycle has thus been formed. The hopelessness and alienation many young inner-city black men and women feel, largely as a result of endemic joblessness and persistent racism, fuels the violence they engage in. This violence serves to confirm the negative feelings many whites and some middle-class blacks harbor toward the ghetto poor, further legitimating the oppositional culture and the code of the streets in the eyes of many poor young blacks. ${ }^{130}$

We see this in the increasing likelihood and severity of punishment that has approached normative levels, compromising the moral component of punishment and in turn the logic of deterrence.

Finally, rapid changes in social structure have altered social organization in specific communities, compromising the informal social controls that reinforce legal controls including punishments. Informal social controls are the regulatory processes of social groups and institutions that convey the rewards and social opprobria for prohibited social behaviors. The salience of informal controls reflects the evaluation of negative social sanctions or rewards as meaningful and worth avoiding, that the status attached to societal acceptance itself is worthwhile, and that the groups allocating informal punishments have legitimacy and moral standing that merit efforts to obtain their acceptance. Structural changes-the concentration of poverty, declining marriage rates, high residential mobility combined with low political participation-have weakened the informal controls of social institutions such as schools and the supervision and cohesion of neighborhood residents. Ultimately, whatever the messages of punishment, their reinforcement through informal (extralegal) mechanisms has been weakened, and deterrent effects once again compromised.

So far we have explained how structural changes in many communitiesespecially high crime communities-have been altered in ways that make it more difficult for residents to exert social control. Because of these changes, we have argued that the effectiveness of deterrence-based formal punishment is likely to be undermined. In this section we focus on the experience of residents of high-crime, minority communities and explain that not only is the increase in formal punishment not likely to be effective for the reasons we have already explained, it is also likely to exacerbate the precursors to low levels of social control such as family disruption, unemployment, and low economic status. When these negative consequences are visited on a class of offenders that are not geographically dispersed but that are instead spatially concentrated, it is possible that the policy that leads to the consequences confounds its own crime-fighting ends.

130 Elijah Anderson, The Code of the Streets, ATL. MONTHLY, May 1994, at 83, available at http://www.theatlantic.com/doc/print/199405/code-of-the-streets. 


\section{A. Family Disruption}

High rates of imprisonment of young African-American men and women translate into many broken families in African-American communities. It is difficult to measure how family ties and connections and individual psyches may be devastated when family members and close friends are removed from communities. Although quantification of emotional harm is practically impossible, some judgments about the ways in which high incarceration levels affect the vitality of families, the life chances of children left behind, and the economic circumstances of African-American communities are possible.

First, imprisonment contributes to the already high percentage of families headed by single African-American women. ${ }^{131}$ Because the mortality rate for African-American men is somewhat higher than that for African-American women, the female to male ratio is already quite high in some African-American communities. ${ }^{132}$ High levels of incarceration of African-American men add to this ratio. Increases in the ratio of African-American women to African-American men are likely to lead to a lower probability of marriage and formation of two-parent families. ${ }^{133}$

Second, the removal of young adults from the community means fewer adults to monitor and supervise children. Inadequate supervision leads to increased opportunities for children to become involved in delinquency and crime. ${ }^{134}$ The increasing rate of African-American women sentenced to prison presents an additional hazard to poor African-American communities and especially to the children growing up in them, though the absolute numbers are small compared to the numbers of African-American men imprisoned. ${ }^{135}$ Bureau of Justice Statistics data for the year 2006 shows that African-American women were incarcerated in

131 Fifty-five percent of African-American family households are headed by women compared to seventeen percent for Whites. See U.S. Census BUREaU, STATISTICAL ABSTRaCT OF THE UNITED STATES 62 (1995), available at http://www.census.gov/prod/1/gen/95statab/pop.pdf.

132 See William A. Darity, JR. \& Samuel L. Myers, JR. With Emmett D. Carson \& WILlIAM SABOL, THE BLACK UNDERCLASS: CRITICAL ESSAYS ON RACE AND UNWANTEDNESS 148-51 (1994) (explaining that mortality rates for black men outpaces that of black women partly because of high homicide rates among young black men).

133 This argument assumes, of course, that the marriage prospects of African-American women are substantially determined by the ratio of African-American men available to African-American women. This assumption is not without foundation. American interracial marriage is still relatively rare-about two percent of all marriages in 1994. See U.S. CENSUS BUREAU, supra note 131, at 55. Moreover, interracial marriage is least likely for African-American women. See id. (chart showing that in 1994 there were 96,000 more black husband/white wife interracial couples than white husband/black wife couples).

134 See Robert J. Sampson \& John H. Laub, Urban Poverty and the Family Context of Delinquency: A New Look at Structure and Process in a Classic Study, 65 CHILD DEV. 523, 531-33, 538-39 (1994).

135 BUREAU OF JUST. STAT., PRISONERS IN 2006, supra note 17, at 6 (estimating that there were 28,600 African-American women incarcerated in state and federal prisons in 2006). 
state or federal prisons at a rate of 148 per 100,000 , whereas the rate for white women was 48 per $100,000 .{ }^{136}$ Because African-American women often are the primary caretakers of children in poor communities, there is a growing risk that children are in danger of losing both parents to the criminal justice system. ${ }^{137}$ As a result, these children face a very high risk of future criminal involvement. Moreover, communities will suffer a loss because each additional incarcerated adult erodes the important community adult/child ratio that is a predictor of greater neighborhood supervision.

\section{B. Low Economic Status and Joblessness}

In addition to the negative consequences that high rates of imprisonment undoubtedly have on the amount of emotional support and caregiving available to the families of incarcerated individuals, high imprisonment rates are likely to have a detrimental effect on the economic well-being of families in impoverished neighborhoods. The prevalence of low economic status and unemployment among families predicts low levels of community social organization. Given the wellestablished association between poverty and families headed by single women, ${ }^{138}$ there can be little doubt that higher rates of incarceration of African-American men will contribute to the deepening poverty in the African-American community. Recent Census estimates indicate that an astonishing 22.3\% of African-American families have incomes below the poverty level compared to $8.1 \%$ for whites. ${ }^{139}$ Families of the incarcerated necessarily lose whatever financial support the offenders could have given them. ${ }^{140}$ Though the majority of those incarcerated are

136 Id. at 7 . Note that the number of African-American women in prison declined from an estimated 32,000 in 2000 to an estimated 28,600 in 2006 . Id . at 6 . Furthermore, those figures increased for white women from 33,300 to 49,100 during this period. Id.

137 A 2000 Bureau of Justice Statistics Special Report, Incarcerated Parents and Their Children, estimated that Black children were nine times more likely than White children to have a parent in prison. See Christopher J. MUMOla, BuREAu of JUST. STAT., InCARCERATEd ChILDREN AND THEIR PARENTS 2 (2000), available at http://www.ojp.usdoj.gov/bjs/pub/pdf/iptc.pdf. See also John Hagan \& Ronit Dinovitzer, Collateral Consequences of Imprisonment for Children, Communities, and Prisoners, 26 CRIME \& JUST. 121 (1999).

138 See WILSON, supra note 108.

139 See U.S. Census Bureau, Statistical Abstract of the United States 42 (2007), available at http://www.census.gov/prod/2006pubs/07statab/pop.pdf. These numbers have also been constant over time with respective rates standing at $31.3 \%$ and $9.4 \%$ in $1995,32.3 \%$ and $9.7 \%$ in $1983,28.1 \%$ and $6.6 \%$ in 1973. Id . at 48 ; U.S. CENSUS BUREAU, supra note 131 , at 484 , available at http://www.census.gov/prod/1/gen/95statab/income.pdf.

140 An interesting statistic from the 1991 Survey of Prison Inmates supports an inference that families are worse off economically after an adult family member is incarcerated. Out of all inmates surveyed whose families were receiving public assistance at the time of the survey interview, fiftyone percent of those families were not receiving public assistance prior to the inmates' arrests. Bureau of Just. STat., SURVey OF STate Prison InMates, 1991, at 3 (1993), available at http://www.ojp.gov/bjs/pub/pdf/sospi91.pdf. 
ill-educated and although many have shallow work histories, ${ }^{141}$ many still manage to contribute to their families financially prior to being imprisoned. Some participate in the "informal economy," running unlicensed cab businesses, car repair businesses, and unlicensed street vending businesses, to name a few, in order to assist their families. ${ }^{142}$ And some of them engage in illegal activity in order to contribute to their families. A recent RAND study documents the importance of drug selling as an economic activity for young black males in the District of Columbia. This study found that over half of the men sampled provided monthly support to a child, spouse, girlfriend, family member, or friend. ${ }^{143}$ Another study of Chicago Public Housing found that many public housing residents rely on gang members for financial support to supplement public assistance benefits. ${ }^{144}$

Most drug offenders do not remain in prison forever, ${ }^{145}$ and we should expect some of the negative financial consequences that families suffer when a contributor is sent away to prison to be alleviated, if only in part, when the offender is released. However, the negative consequences to the community are not likely to be remedied simply by the release of drug offenders. In fact, release of convicted drug offenders back into their communities may worsen the social organization of poor communities even while the convict's return may improve the financial situation of his family.

The vast majority of formerly incarcerated men return to their homes in the inner city, where job prospects for everyone already are glum, even if they are aware of better job prospects elsewhere. ${ }^{146}$ In 1997 the Bureau of Labor Statistics

141 According to the 1991 Survey of State Prison Inmates, $65.1 \%$ of all state prison inmates have less than a high school education. Id. Moreover, in $199132.7 \%$ of all state prison inmates were not employed at the time of arrest. See U.S. CENSUS BUREAU, supra note 131, at 217, available at http://www.census.gov/prod/1/gen/95statab/law.pdf.

${ }^{142}$ See, e.g., Sudhir Alladi Venkatesh, Cleaning Up Chicago's Public Housing: A Critique Of "Sweeps" and Enforcement-Based Approaches, in EIGHTH ANNUAL INTERNATIONAL CONFERENCE ON Drug Policy Reform, "The Crucial Next Stage: Health Care \& Human Rights" 5 (1994) (explaining the entrenched informal economy in Chicago's public housing).

143 See Peter Reuter, Robert MacCoun \& Patrick Murphy, Rand, Money from Crime: A StUdy OF THE ECONOMICS OF DRUG DEALING IN WASHINGTON, D.C., 70 (1990), available at http://www.rand.org/pubs/reports/2005/R3894.pdf.

144 See Venkatesh, supra note 112, at 251-52.

145 For offenders convicted and sentenced in U.S. District Courts in 1992, the average sentence length was 21.8 months for a possession offense and 83.8 months for a trafficking or manufacturing offense. See U.S. CENSUS BUREAU, supra note 131, at 214, available at http://www.census.gov/prod/1/gen/95statab/law.pdf. A survey of 38 states found the average maximum sentence length to be 53 months for possession and 61 months for trafficking. Most telling, however, are the statistics on time served. In federal prisons, average time served totaled 8.2 months for possession and 34.7 months for trafficking, while for the states the averages were 15 and 18 months respectively. See BurEau of Just. Stat., Sourcebook of Criminal Justice STATISTiCS supra note 17 , at 555-56, 574.

146 See john a. powell, Race and Poverty: A New Focus for Legal Services, 27 Clearinghouse Rev. 299, 303 (1993) (documenting the fact that imprisoned men usually return to 
estimated the unemployment rate in central cities to be $7.3 \%$ compared to $4.0 \%$ in suburbs of central cities and $4.9 \%$ in the balance of the country; however, researchers have documented jobless rates as high as $60 \%$ in some hyper-poverty areas in central cities. ${ }^{147}$ This latter statistic is important. Unlike the term unemployment, which assumes an individual is a participant in the formal labor market, joblessness refers to those who have completely withdrawn from the labor force-they are not working nor are they actively looking for work.

Of course, legitimate job prospects for ex-convicts are likely to be worse than the already weak prospects for inner city residents generally. As we noted above, few people with the typical convict's credentials would be competitive in today's service-oriented economy, which emphasizes educational attainment and training. ${ }^{148}$ Thus, a released convict likely will have even fewer employment opportunities than he had before he was imprisoned, so he will inevitably contribute to the already high rates of unemployment in the central cities when he returns home-unemployment that erodes community social organization.

Professor Bruce Western, in his 2006 book, Punishment and Inequality in America, provides statistical evidence for this proposition. ${ }^{149}$ Western presents detailed information about hours worked and wages for those never incarcerated and compares those figures to hours worked and wages for those individuals both before and after incarceration. ${ }^{150}$ Although the largest intraracial wage gap is that between whites who are never incarcerated and whites who end up in the criminal justice system at some point, with average hourly wages of $\$ 14.70$ versus $\$ 11.14$, African Americans who have been incarcerated experience the largest drops in earnings. Black offenders earned $\$ 7,020$ in the year after reentry versus $\$ 13,340$ in the year before their incarceration. ${ }^{151}$ "These raw figures suggest that incarceration damages the employment prospects of men with criminal records, but it is also clear that men bound for prison, even before they are incarcerated, do worse on the job market than the rest of the population." 152 A statistical analysis intending to isolate the effect of incarceration (rather than one also reflecting labor market differences that might result because individuals who go to prison have fewer opportunities in the legitimate labor market) demonstrates that "[m]en with prison records are estimated to earn 30 to 40 percent less each year."153 More ominously,

the impoverished urban communities they came from, even if better jobs are located elsewhere).

147 See BUREAU OF LABOR STAT., ISSUES IN LABOR STATISTICS (1998), available at http://ww.bls.gov/opub/ils/pdf/opbils27.pdf. See also WILSON, supra note 54, at 19.

148 Professor Randolph Stone has said that a felony conviction for an African-American youth is an "economic 'life sentence." " Randolph N. Stone, Juvenile Justice: A Dream Deferred, 8 CRIM. JUST. i, 50 (1994).

149 WESTERN, supra note 5, at 116.

150 Id. at 115-16; stated in 2004 nominal dollars.

151 Id. at 115.

152 Id.

153 Id. at 120. 
in terms of advocates' preference for ensuring that reentering individuals establish a permanent presence in the legitimate job market, there are issues of rapid job turnover and insufficient wage growth.

Moreover, Western cites research by Professor Devah Pager demonstrating pernicious discrimination among reentering individuals, particularly African Americans. ${ }^{154}$ The study involved "randomly assign[ing] resumes to pairs of specially trained black and white job applicants. The resumes showed identical work experience and education, but one of the two indicated recent employment in prison and listed a parole officer as a reference."155 After having these applicants interview for 350 jobs in Milwaukee in 2001, Pager found that Whites without a criminal record were offered second-round interviews from employers $34 \%$ of the time (versus $17 \%$ for those who said they were in prison); the corresponding rates for Blacks were $14 \%$ and $5 \% .^{156}$ Western also discusses legal disqualifications from employment in certain licensed or professional occupations, the erosion of job skills during incarceration, the "signaling" effect of untrustworthiness that incarceration may convey to potential employers, and the erosion of social and community bonds that often help individuals to find a job. ${ }^{157}$

Furthermore, Jeremy Travis argues that mass incarceration is counterproductive because it may have criminogenic effects on prisoners. ${ }^{158}$ Imprisonment not only weakens a person's access to legal work, as both Western's and Pager's research has shown, it also strengthens his connections to criminal networks. ${ }^{159}$ Thus, upon re-entry to their communities, prisoners pull away from legal work and "push toward the secondary labor market of day labor and part-time jobs and toward illegal income."160

One might think that the argument that a released convict will contribute to high rates of unemployment upon re-entry is undercut by the fact that many convicted offenders did not participate in the formal labor force prior to incarceration. Under such conditions, it may be difficult to see how a convict's return to his neighborhood would substantially worsen the neighborhood's social organization. In fact, one might even predict that many families would be better off once an offender is released because the newly-released offender is able to contribute to his family financially, or in other ways, as he was not able to do in prison. Notwithstanding the fact that the unemployed released convict may be able

154 See Devah Pager, Marked: Race, Crime, and Finding Work in an Era of Mass INCARCERATION (2007); Devah Pager, Two Strikes and You're Out: The Intensification of Racial and Criminal Stigma, in BARRIERS TO REENTRY? THE LABOR MARKET FOR RELEASED PRISONERS IN POSTINDUSTRIAL AMERICA 151 (Shawn Bushway, Michael A. Stoll \& David F. Weiman eds., 2007).

155 WESTERN, supra note 5, at 112.

156 Id.

157 Id. at 112-13.

158 TraVIS, supra note 20 , at 166.

159 Id.

160 Id. 
to enhance his family's welfare when he returns home, it is important to see that release of convicted drug offenders back into poor communities has the potential to erode a community's social organization even if the proportion of unemployed individuals in the community is essentially unchanged.

The widespread human capital in a community facilitates the formation of networks and relationships among individuals that form the backbone of the structural components of social organization; however, the status of "convict" severely compromises the released felon's ability to expand his human capital. A released convict may perceive further investment in human capital to be useless because he may understandably reason that sinking money and time into education and training will not overcome the stigma of a felony conviction on a job application. When he makes the decision to refrain from further investment, he weakens existing relationships he has with people who will be less likely to depend on him because his ability to provide them with benefits through interaction is compromised. Additionally, the individual who decides not to make further investments in education, skills, and training cuts himself off from potentially useful relationships with others who have no incentive to form relationships with him.

It is true that many law-abiders in the neighborhoods we are concerned with here possess low levels of human capital, as poverty often is correlated with low levels of education. By distinguishing convicted drug offenders from law-abiders, we do not mean to imply that it is a fairly simple proposition for residents of poor, urban communities to invest in human capital by acquiring better educations and vocational skills. However, we do mean to argue that, to the extent that it is difficult for anyone in poor communities to do so, it is that much harder for a released convict; the marginal effect of this additional hurdle may make a large difference in the potential of the convict to form important networks with his neighbors. The basic point is this: all unemployed populations are not equal, and any incremental increase in the proportion of convicts among the unemployed population of the ghetto portends incrementally worse consequences for the vitality of the community.

To emphasize the point that increases in the proportion of the community's population of those with the status of "convict" potentially erodes the social organization of a neighborhood, consider the likely change that ascription of the status will produce in the level of an individual's interaction with law enforcement or in that individual's level of civic participation. A released convict obviously will be less likely than other law-abiding neighborhood residents to engage positively with local law enforcement. Of course, many non-convicts in poor, minority communities may not welcome engagements with law enforcement. The point, however, is that released convicts are even less likely than others to do so.

Voting is another indicator of participation in the life of a community. In ten states, convicts are unable to vote upon the completion of their sentences, ${ }^{161}$ The

161 See Brennan CTR. For Just., Criminal Disenfranchisement LaWs ACross the UNITED 
burden of these laws falls disproportionately on African Americans and Hispanics: approximately thirteen percent of African American men cannot cast votes, and in three states, the percentage rises to twenty because they are either currently or formerly incarcerated. ${ }^{162}$ Restoring the vote to ex-felons is complex and burdensome, with the result that many never regain the right to vote. ${ }^{163}$ Voting is connected to other forms of political participation such as membership in formal organizations, an important structural component of social organization. ${ }^{164}$ These arguments, together with those in the previous paragraph, illustrate that changes in the percentage of individuals with the status of "convict" in the community potentially affect the prevalence of friendship networks in a community and the levels of participation by neighborhood residents in formal organizations.

Finally, release of incarcerated drug offenders is unlikely to remedy the first precursor to social organization disruption referred to earlier-family disruption. Even while a released convict may contribute to his family in small and helpful ways, it is unlikely that release will lead to strengthening of family ties and aversion of family disruption. With dismal employment prospects, the released convict may not be viewed as a favorable "marriage prospect."165 If the released convict was married prior to incarceration, his now-impaired economic

STATES (2008), available at http://www.brennancenter.org/page/-/d/download_file_48642.pdf. In 25 states, felons can regain the right to vote only after completion of probation, parole or prison sentences, and often only upon application. See also MARGARET Colgate LOVE, THE SeNTENCING Project, Relief From the Collateral Consequences of a Criminal Conviction: A State-byState Resource Guide Tbl. 7 (2006); The Sentencing Project, Felony Disenfranchisement LAWS IN THE UNITED STATES, available at http://www.sentencingproject.org/Admin/Documents/publications/fd_bs_fdlawsinus.pdf (finding that 5.3 million Americans, including 1.4 million African-American men, are temporarily or permanently disenfranchised because of a felony conviction); Andrew L. Shapiro, Challenging Criminal Disenfranchisement Under the Voting Rights Act: A New Strategy, 103 YALE L. J. 537, 538-40 (1993) (finding that about four million Americans, disproportionately African-American, have lost their right to vote because of a criminal conviction).

162 Among prison inmates in Rhode Island, African-American inmates outnumber Hispanics by two to one, and Whites by six to one. See ERIKA WOOD, RESTORING THE RIGHT to VOTE 8, 21 (2008), available at http://www.brennancenter.org/page/Democracy/Restoring\%20the\%20Right\%20to\%20Vote.pdf.

163 JeFF MANZA \& Christopher UGgen, Locked OUT: FELON DISENFRANCHISEMENT AND AMERICAN DEMOCRACY 252-54 (2006) (showing that among 155,127 men and women released from prison in Mississippi between 1992 and 2004, only 107 petitions to restore their voting rights were approved, and that the potential African-American electorate in Kentucky has been reduced by almost 24\% during the same period). See also Jason DeParle, The American Prison Nightmare, 54 N.Y. REV. OF BOOKS 33 (Apr. 12, 2007).

164 See SIDNEY VERBa, KAy LEHMAN SCHLOZMAN \& HENRY E. BRADY, VoICE AND EQUALITY: CIVIC VolunTARISM IN AMERICAN POLITICS (1995).

165 WILSON, supra note 108, at 81-92 (discussing the "male marriageable pool index," the ratio of employed civilian men to women of the same race and age-group, and showing that the decline in the proportion of employed black men to women of the same age tracks the decline in the formation of black two-parent households). 
circumstances likely will place strains on his relationship. ${ }^{166}$ Higher numbers of families headed by single women seem inevitable even after incarcerated men are released. Also, to the extent that a single woman has managed to create a stable home life while the father of her children was incarcerated, his release may lead to disruptive domestic violence. ${ }^{167}$

This analysis should demonstrate that a law enforcement strategy that depends on the high prevalence of long sentences to generate benefits may ultimately backfire. The strategy could likely lead to family disruption, unemployment, weakened informal social controls among neighbors, and lower levels of civic participation. ${ }^{168}$ Thus, to the extent that the strategy produces crime reduction benefits, it does so only by exacerbating the preconditions of social organization disruption.

\section{THE IMPACT OF FORMAL PUNISHMENT AND PERCEPTIONS OF LEGITIMACY}

How do the impacted African-American communities view the substantial increase in punishment over the last two decades? The answer to that question is complex. African Americans generally, and those who reside in high-crime neighborhoods especially, have multiple reasons to hold complex views about the issue. $^{169}$

As noted earlier, the level of African-American imprisonment is greatly affected by sentencing policy directed at drug offending, and one undisputed consequence of the War on Drugs is the fact that disproportionate numbers of African Americans (poor African Americans in particular) have been convicted and imprisoned for drug offending. President George H. W. Bush's Attorney General, William Barr, touted this piece of data claiming that " $[t]$ he benefits of increased incarceration would be enjoyed disproportionately by black Americans." $" 170$ However, assessing the extent to which African Americans enjoyed the claimed benefits of the policy is difficult. ${ }^{171}$ Drug selling and drug use

166 See Sampson, supra note 100.

167 See Anthony E.O. King, African-American Males in Prison: Are They Doing Time or is the Time Doing Them?, 20 J. Soc. \& SOC. WELfare 9 (1993) (explaining how prison life can make former inmates prone to violence).

168 See James P. Lynch \& William J. Sabol, Commentary, Assessing the Effects of Mass Incarceration on Informal Social Control in Communities, 3 CRIMINOLOGY \& PUB. POL'Y 267 (2004) (offering empirical evidence of the connection between community disruption and mass imprisonment and concluding in part that the long-term result of mass incarceration is to reduce its overall effectiveness in reducing crime rates.). See also Tracey L. Meares, Mass Incarceration: Who Pays the Price for Criminal Offending?, 3 CRIMINOLOGY \& PUB. POL'Y 295 (2004).

169 See generally Meares, supra note 28.

170 See TONRY, supra note 6, at 36.

171 In 1985, approximately $11.4 \%$ of current cocaine users were Black-roughly the percentage of African Americans in the population. See John P. Walters, Race and the War on Drugs, 1994 U. CHI. LEGAL F. 107, 135 (1994). In 1988, 15.3\% of current cocaine users and 27.3\% of frequent cocaine users were Black. Id. at 136 . By $1991,21.8 \%$ of current cocaine users were 
unfortunately are prevalent in modern urban ghettoes where many poor African Americans reside, suggesting that many African Americans could benefit from federal and state crackdowns on drug offenders. At the same time, it is impossible to ignore the fact that " $[t]$ he young black men wreaking havoc in the ghetto are still [considered] 'our youngsters' in the eyes of many decent poor and working-class black people who are sometimes their victims." ${ }^{172}$ In light of such beliefs, it is difficult to be confident that African Americans, though supposedly beneficiaries of prevalent and long sentences for drug offending, wholeheartedly support them. ${ }^{173}$ In short, while African Americans disproportionately suffer problems associated with drug use and marketing, they also suffer the negative consequences associated with the current drug-law enforcement regime.

So far we have explained reasons to be skeptical of the benefits flowing from the escalation of formal punishment to achieve deterrence of crime-especially drug offending. There are also reasons to believe that the racial asymmetry generated from high levels of punishment of inner city offenders is likely to ultimately undermine the goal of crime reduction. The race-specific reasons that undermine the ability of a law-and-order program to effect substantial crime reduction in inner city communities fall into three general categories: stigma, linked fate, and multiple roles.

Black, and $41.2 \%$ of frequent cocaine users were Black. Id. at 137 . Although the numbers of all current and frequent cocaine users have declined since 1985, the numbers of White current and frequent cocaine users declined most dramatically. The result is an increasingly disproportionate representation of Blacks among illegal drug users, though White users still remain the majority of users. These data could suggest that if the War on Drugs was responsible for declining drug use, it was less effective among Blacks than Whites. This argument depends, however, on an assumption that the rate of increase of use among Blacks and Whites during the period in question was the same. If the rate of increase of use among Blacks was faster than that among Whites, these data could also suggest that the War on Drugs was just as effective among Blacks as it was among Whites-perhaps even more effective. The 1997 National Household Survey on Drug Abuse seems to show a different picture. See Off. of Applied Stud., Dep't Of Health \& Hum. Serv., 1997 National Household SURVEY ON DRUG ABUSE, available at http://www.oas.samhsa.gov/nhsda/1997Main/nhsda1997mfWeb-39.htm\#Table4.5.

172 Glenn C. Loury, Listen to the Black Community, PUB. INT. 33, 35 (1994).

173 For instance, Bobo and Johnson conducted a study to see the effect racial cues would have on support for capital punishment and the crack-cocaine disparity. While the inclusion of racial cues did not have much effect on support for the death penalty, support for higher sentences for crack was halved among both African Americans and Whites when a question about support for the differential was preceded by a comment about the racial disparities between crack and cocaine users. The survey results demonstrate a tension in the African-American community, whereby concerns about the faimess of a differential policy must also confront concerns about the criminality that crack use produces in their communities. See Lawrence D. Bobo \& Devon Johnson, A Taste for Punishment: Black and White Americans' Views on the Death Penalty and the War on Drugs, 1 Du Bors Rev. 151, 167 (2004); see also Meares, supra note 28. 


\section{A. Stigma}

It appears fairly clear that the disproportionate involvement of minorities (African Americans in particular) in the criminal justice system generally stigmatizes all minorities, whether they are categorized as law breakers or law abiders. ${ }^{174}$ This point is an unremarkable one. Less obvious is the link between the stigmatization of minority law-abiders and their commitment to law abiding conduct. By referring to "commitment to the law" here, we adopt a normative view of compliance whereby a social group promotes respect for authorities and commitment to law as a key value to pass on to other members of the group. Stigmatization of minority law abiders through law enforcement programs that generate extremely racially disproportionate incarceration rates can undermine commitment to the law by minority law abiders by fostering a perception of illegitimacy of government among members of the stigmatized minority group.

Scholars have noted that discrimination undermines minority citizen perceptions of fairness of the criminal justice system. ${ }^{175}$ Although crime rates have declined significantly since the early 1990s, the rates for African Americans remain higher than the rates for both Whites and Hispanics. In the aftermath of the riots that decimated urban areas throughout the country in the mid-1960s, the Kerner Commission characterized how policemen in the ghetto become "the tangible target for grievances against shortcomings" that pervaded law enforcement and criminal justice systems, and that the police and society must "take every possible step to allay grievances that flow from a sense of injustice and increased tension and turmoil." 176 But in the intervening years, any substantial political support for extensive policies to remedy the underlying causes of the riots dissipated.

Glenn Loury offers a compelling historical rationale for the racial discrepancy in attitudes toward the legitimacy of legal outcomes. He argues that "the social meaning of race emergent in American political culture at mid-nineteenth century was closely connected with the slaves' dishonorable status," and consequently "that black Americans are exceptional in the extent to which remnants of this

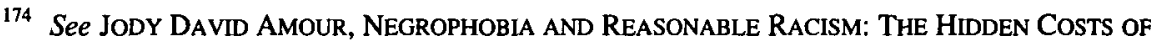
BeING Black IN America (1997); Dinesh D'Souza, Myth of the Racist Cabbie, NAT'L Rev., Oct. 9, 1995, at 36; Walter E. Williams et al., The Jeweler's Dilemma, New REPUBLIC, Nov. 10, 1986, at 18.

175 See, e.g., Tom R. Tyler \& Yuen J. Huo, Trust in the Law: Encouraging Public COOPERATION WITH THE POLICE AND COURTS (2002); Lawrence D. Bobo \& Victor Thompson, Unfair by Design: The War on Drugs, Race, and the Legitimacy of the Criminal Justice System, 73 Soc. REs. 445 (2006); Bobo \& Johnson, supra note 173; Jason Sunshine \& Tom R. Tyler, The Role of Procedural Justice and Legitimacy in Shaping Public Support for Policing, 37 LAW \& Soc'Y REv. 513, 519-21 (2003) (suggesting that police treatment of people in the community has stronger effect on legitimacy than quality of police performance); Tom R. Tyler \& Jeffrey Fagan, Legitimacy and Cooperation: Why Do People Help the Police Fight Crime in Their Communities?, 6 OHо ST. J. CRIM. LAW 231 (2008).

176 THE KERNER REPORT: THE 1968 REPORT OF THE NATIONAL ADVISORY COMMISSION ON CIVIL DISORDERS 300 (1988). 
ignoble history are still discernible in the nation's present-day public culture."177 He explains how the pervasive societal stigmatization of African Americans can further marginalize the community from the institutions and norms that "mainstream" society purports to value. ${ }^{178}$

As Loury explains, the "social otherness" engendered by centuries of racial subordination infects social meaning, most notably the paradigm of how society conceptualizes policies and situations, if not the attitudes individual Americans say they hold. ${ }^{179}$ He illustrates the effect of social meaning by noting how "[t]he youthful city-dwelling drug sellers elicit a punitive response, while the youthful suburban-dwelling drug buyers call forth a therapeutic one."180 Racial stigma, as evidenced by the development of urban ghettos, "helped create the facts that are its own justification." ${ }^{\prime 81}$ Despite the pervasive evidence of minority skepticism of the fairness of the criminal justice system and law enforcement authorities, very few scholars have linked these perceptions to predict behavior of minority group members. ${ }^{182}$

Certainly, widely shared perceptions of unfairness, ill treatment, and racial animus can erode popular support for law and the moral and social norms that underlie them. ${ }^{183}$ These are the moving parts in a legitimacy story and would apply to most social groups. But to understand exactly how legitimacy may support or corrode beliefs in and compliance with the law, these linkages need to be spelled out in more precise theoretical detail. What, then, is legitimacy, what

177 GlenN C. Loury, The Anatomy of RaCial Inequality 69 (2002).

178 Id. See also Glenn C. Loury, Why Are So Many Americans in Prison? Race and the Transformation of Criminal Justice, BOSTON REV., July 2007, available at http://www.bostonreview.net/BR32.4/article_loury.php [hereinafter Loury, Americans in Prison].

179 LOURY, supra note 177 , at $70-71$.

$180 \mathrm{Id}$. at 71.

181 Id. at 78.

182 For notable exceptions, see Katheryn K. Russell, The Racial Hoax as Crime: The Law as Affirmation, 71 IND. L.J. 593 (1996) (arguing that perceptions of unfairness in the system support a theory of defiance whereby Black men especially become alienated from "mainstream" values, ultimately reject them as illegitimate, motivating lawbreaking); John Hagan, Carla Shedd \& Monique R. Payne, Race, Ethnicity, and Youth Perceptions of Criminal Injustice, 70 AM. SoC. REv. 381 (2005) (showing that adolescents who perceive discrimination by criminal justice agents are more likely to engage in law violation); Janice Nadler, Flouting the Law, 83 TEX. L. REv. 1399 (2005) (showing that persons who perceive laws as unjust were more willing to flout unrelated laws, and their willingness to disobey extended unrelated laws in their everyday lives such as traffic violations, petty theft, and copyright restrictions). See also TOM R. TYLER, WhY PEOPLE OBEY THE LAW 34-35 (2006) (studies cited in charts on these pages identify a connection between political alienation and support for revolutionary behavior).

183 Hagan et al., supra note 182; see, e.g., David S. Kirk \& Andrew V. Papachristos, Legal Cynicism and the Framing of Neighborhood Violence: Implications For 'Neighborhood Effects' Research 2 (Dec. 28, 2007) (unpublished manuscript), available at http://ssrn.com/abstract=1081894 (showing that elevated rates of legal cynicism in neighborhoods explain "homicide net of neighborhood structural conditions and collective efficacy", and "the persistence of homicide in certain Chicago neighborhoods during the 1990s when homicide declined drastically city-wide"). 
are its antecedents, and from what experiences or norms does it develop? The term is used widely and promiscuously in legal scholarship, moral philosophy, and political science but generally without consensus as to its definition, how it accrues, or its influence on normative action. ${ }^{184}$

Writing about the challenge of legitimacy in the development of the European Union, David Beetham and Christopher Lord define legitimacy as the moral or normative standing of political authority. ${ }^{185}$ They characterize legitimate regimes as "rightful" governments where "those subject to political authority . . . have an obligation to obey it."186 However, they are concerned less with the mechanisms by which political order and obedience are sustained or break down, than with explaining differences between countries or group differences in the relationship that each holds with a shared government. ${ }^{187}$

Following Beetham, we view legitimacy as the perceived obligation to comply with both civil and criminal law and to defer to decisions of legal authorities. ${ }^{188}$ Legitimacy is a socially and morally salient belief to which social authorities can appeal to gain public deference and cooperation. ${ }^{189}$ It both assumes

184 See generally Brian E. Butler, Posner's Problem with Moral Philosophy, 7 U. CHI. L. SCH. Roundtable 325, 332 (2000) (book review); Williamson M. Evers, Social Contract: A Critique, $1 \mathrm{~J}$. LIBERTARIAN STUD. 185 (1977), available at http://www.mises.org/journals/jls/1_3/1_3_3.pdf; William G. Merkel, Parker v. The District of Columbia and the Hollowness of Originalist Claims to Principled Neutrality, 18 GEo. MASON U. Crv. RTs. L.J. 251, 262-63 (2008); Note, The Charming Betsy Canon, Separation of Powers, and Customary International Law, 121 HARV. L. REv. 1215, 1216 (2008); Arthur Isak Applbaum, Legitimacy in a Bastard Kingdom, (Ctr for Pub. Leadership, Working Paper, 2004), available at http://www.ksg.harvard.edu/leadership/images/stories/ksg/PDF/Publications/applbaumworkingpaper. pdf; Lawrence Solum, Legal Theory Lexicon: Legitimacy (2007), http://lsolum.typepad.com/legaltheory/2007/07/legal-theory--4.html.

185 David Beetham \& Christopher Lord, Legitimacy and the European Union, in PoLrTICAL THEORY AND THE EUROPEAN UNION 15, 15 (Albert Weale \& Michael Nentwich eds., 1998).

186 DAVID BEETHAM \& Christopher LORD, LegItIMACY AND THE EUROPEAN UNION 1 (Longman, 1998)

187 Id. at 20-25. See, e.g., MAX WEBER, ECONOMY AND SOCIETY: AN OUTLINE OF INTERPRETIVE SOCIOLOGY 212-15 (Guenther Roth \& Claus Wittich eds., 1978) (1968).

188 See, e.g., DAVID BeETHAM, The Legrtimation OF POWER 15-16 (1991) (defining legitimacy along three dimensions, including rules that are justified "by reference to beliefs shared by both dominant and subordinate"); Tom R. Tyler, Psychological Perspectives on Legitimacy and Legitimation, 57 ANN. ReV. PSYCHOL. 375 (2006) [hereinafter Tyler, Psychological Perspectives] (discussing ways in which legitimacy facilitates state exercise of power because individuals view authorities as morally or normatively appropriate); TYLER, supra note 182, at 25 (stating that "legitimacy exists when the members of a society see adequate reason for feeling that they should voluntarily obey the commands of authorities"); Tyler, Psychological Perspectives, supra at 378 ("One aspect of values-obligation-is a key element in the concept of legitimacy. It leads to voluntary deference to the directives of legitimate authorities and rules."). But see WEBER, supra note 186. See also Tyler \& Fagan, supra note 175.

189 Herbert C. Kelman \& V. Lee Hamilton, Crimes of Obedience: Toward a Soctal PSYCHOLOGY OF AUTHORITY AND RESPONSIBIITY (1990); TYLER, supra note 182; TYLER \& HUO, supra note 175; John R. P. French, Jr. \& Bertram Raven, The Bases of Social Power, in STUDIES IN 
and requires that citizens perceive an obligation to obey legal authorities and also hold trust and confidence in authorities. Legitimacy, then, may be strongest when law and legal actors express moral and social norms that are widely shared by both dominant and subordinate social groups. In the context of this essay, legal actors, especially the police-because they are a common and frequent point of contact with the state for most citizens - can gain cooperation and compliance by inculcating the popular perception that their actions and decision are legitimate. This argument builds upon a long line of theory that argues for the centrality of legitimacy to the effectiveness of state actors. ${ }^{190}$

Psychologist Tom Tyler advances a normative view of compliance with the law that promotes the fact that people tend to comply with the law because they believe that authorities have the right to dictate to them proper behavior-that they believe that authorities are legitimate. ${ }^{191}$ The normative view of compliance, in contrast to an instrumental one, emphasizes the importance of the social influence of groups on individuals. Individuals respond to normative factors differently from the way they respond to rewards and punishments. In contrast to the individual who complies with the law because she is responding to externally imposed punishments, the individual who complies for normative reasons does so because she feels an internal obligation. ${ }^{192}$ It is "[t]he suggestion that citizens will voluntarily act against their self-interest [that] is the key to the social value of normative influences." 193

Although the link between perceptions of legitimacy of government and compliance with the law has long been discussed in the theoretical and empirical social science literatures, ${ }^{194}$ empirical support for this point has been equivocal. ${ }^{195}$

SOCIAL POWER 150, 155-65 (Dorwin Cartwright ed., 1959) (identifying six dimensions of organizational power, including legitimacy, that can produce compliance among subordinates: reward power (perceived ability to give positive consequences or remove negative ones), coercive power (perceived ability to punish those who not conform with your ideas or demands), legitimate power, or organizational authority (perception that someone has the right to prescribe behavior due to election or appointment to a position of responsibility), referent power (through association with others who possess power), expert power (distinctive knowledge, expertness, ability or skills), and information power (control of information needed by others in order to reach an important goal). See also TYLER, supra, at 170-78 (suggesting psychology of legitimacy wherein people obey authorities and institutions that they trust).

190 See BeETHAM, supra note 188. See also WeBER, supra note 187.

191 See TYLER, supra note 182, at 25. Professor Tyler also notes that people may also comply with the law because they believe that the law dictates behavior that accords with their own sense of personal morality. Tyler warns that personal morality is "double-edged" because it may or may not comport with the dictates of legal authorities. Id.

192 Id. at 24.

$193 \mathrm{Id}$.

194 Id. at 24-27 (summarizing research on compliance with legal norms and legitimacy of legal institutions).

195 Id. at 27. 
Work by Tyler nearly two decades ago systematically explored the connection between citizen perceptions of fairness and legitimacy and compliance, and this work supports the claim that extreme racial asymmetry in punishment can undermine compliance with law among minority groups. Tyler's work shows that compliance with the law is strongly related to a citizen's perceptions of legitimacy of government. ${ }^{196}$ His study of the experiences, attitudes, and behavior of a random sample of citizens in Chicago demonstrates that perceptions of legitimacy independently contribute to compliance. Moreover, Tyler shows that this has a greater impact on compliance than fear of sanction, or on the particular outcomes of the interactions of citizens with legal or other government institutions. ${ }^{197}$ More recently, Tyler and Fagan have replicated these results in New York, focusing specifically on the interactions of citizens with police and criminal actors. ${ }^{198}$

Professor Tyler, along with Tyler and Fagan, show that experience-based assessments of both distributive fairness ${ }^{199}$ and procedural fairness ${ }^{200}$ matter a great deal to perceptions of legitimacy and compliance, especially among African Americans. ${ }^{201}$ In Tyler's 1990 research, he surveyed residents of Los Angeles neighborhoods of varying ethnic and racial composition to assess the relationship between procedural justice, distributive justice, and the acceptance of decision outcomes by legal actors. For Hispanics, their acceptance of decisions and satisfaction with the decision-maker was mediated by their experience at the hands of legal actors, specifically "quality of treatment" and "procedural justice." The outcome itself was unrelated to their acceptance and favorable rating of that outcome. For African Americans, however, both procedural and distributive justice were closely tied to acceptance of decisions. Moreover, procedural justice was important only in conjunction with distributive justice, not by itself. ${ }^{202}$ In other words, for African Americans, "fairness" in the process is not easily separated from equity in the outcomes of the process.

Professor Tyler and his colleagues confirmed this finding in a national survey on views of the courts. Overall, the quality of treatment by legal actors was the

196 Id. at 64 ("People who regard legal authorities as legitimate are found to comply with the law more frequently.").

197 Id. A caveat is in order. Professor Tyler explored adherence to laws that would not be considered by most to be serious crimes if broken-speeding and parking violations, shoplifting, and the like. Tyler's focus is on compliance with the law by those generally considered to be lawabiding.

198 Tyler \& Fagan, supra note 175, at Tables 4-6, 254, 257, 259.

199 See TYLER, supra note 182, at 73 (explaining that the concept of distributive faimess emphasizes the ways in which "citizens evaluate public policies by examining the extent to which they distribute government benefits and burdens fairly"). See also Tyler \& Fagan, supra note 175.

200 "According to theories of procedural justice, citizens are not only sensitive to what they receive from the police and the courts but also responsive to their own judgments about the faimess of the way police officers and judges make decisions." TYLER, supra note 182, at 73.

201 TyLER \& HuO, supra note 175.

202 Id. at 134. 
most significant predictor of a favorable view of the courts. Both process issues and outcome fairness are important for all racial and ethnic groups in their interactions with legal authorities to assess procedural justice. ${ }^{203}$ However, African Americans and Hispanics are less concerned than Whites with process issues, while Whites are more likely to rely on their assessments of process in estimating satisfaction with legal decisions. Minorities emphasize outcome issues more in assessing procedural justice, though the differences are small and the process issues are overall more important influences on their willingness to accept legal decisions. ${ }^{204}$ Procedural justice weighed far more than distributive justice in the evaluation of the courts among Whites and Hispanics. African Americans were unwilling to place trust in courts and legal actors without trust in the fairness of substantive outcomes.

The disproportionate representation of minorities in prisons is linked to notions of distributive and procedural justice in a fairly obvious way. If members of a minority group do not believe that the prison sentences that members of their group receive are fairly distributed, then they may conclude that the policy that produces the unfair distribution is illegitimate. ${ }^{205}$ If minority group members reach this conclusion because the law and order program produces asymmetrical incarceration rates, then Tyler's model suggests that members of the group are less likely to comply with the law.

Since then, further empirical and ethnographic evidence has tended to bolster that contention. In 2006, the New York Police Department conducted 506,491 documented stops, with arrests or summonses resulting less than one-tenth of the time; moreover, since African Americans represented 53\% of those stops while constituting $24 \%$ of New York's population, it is clear that law-abiding African Americans disproportionately endure adversarial contacts with the police. ${ }^{206}$ Such interactions with the police can profoundly shape how individuals view police legitimacy and thereby how they subsequently interact with law enforcement. While New York adopted zero-tolerance policing under the "broken windows" theory of criminality, recent research has questioned the connection between disorder and crime; such zero-tolerance plans therefore have the perverse effect of

203 Id. at 154.

204 Id. at 155.

205 Empirical work indicates that Blacks are much more likely than Whites to believe that courts are much too harsh on criminal offenders. See, e.g., Meares, supra note 28.

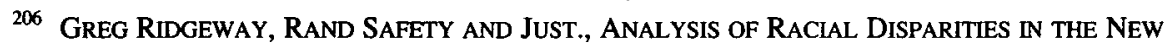
YORK POLICE DEPARTMENT's STOP, QUESTION, AND FRISK PRACTICES 10, 19 (2007), available at http:/www.rand.org/pubs/technical_reports/2007/RAND_TR534.pdf. While the study is able to narrow the racial gap by considering a number of other factors, African Americans are nevertheless subject to stop and to frisking more than white pedestrians in New York. Moreover, among those stopped, police were slightly more likely to frisk African Americans than Whites in similar circumstances. Id. at 33-35. Even if the NYPD's stop practices do not exhibit any unwarranted racial disparities, the higher likelihood of negative police interactions for African Americans may impact their perceptions of police legitimacy. 
antagonizing minority communities and undermining the legitimacy of law enforcement. $^{207}$

A recent study establishes the effects of attitudes of the New York Police Department's legitimacy on behavioral compliance with the law. ${ }^{208}$ Legitimacy is primarily predicated on beliefs in procedural justice, with lesser effects for distributive justice and police performance. Legitimacy is fundamentally based upon the fairness of police interactions, rather than upon instrumental perceptions of police efficacy, and the strength of these attitudes affects compliance with the law, cooperation with police, and the willingness to further empower law enforcement. ${ }^{209}$ Those findings are further bolstered by a forthcoming analysis illustrating that personal experiences with the police that are perceived as procedurally just enhance people's trust and confidence in the police even where negative personal outcomes result. ${ }^{210}$

The development of skepticism regarding law enforcement begins during childhood and adolescence and exhibits behavioral responses comparable to those of adults. A comparative study of youth in two Brooklyn neighborhoods demonstrates declines in perceptions of law enforcement legitimacy as youth become older, and that these perceptions affect compliance and cooperation with law enforcement. ${ }^{211}$ The process of legal socialization, whereby children develop conceptions of the legitimacy of the law, often as a result of their own interactions, affects compliance and cooperation with law enforcement. ${ }^{212}$ Similar results were demonstrated by an empirical study of Chicago youth; the study demonstrated that police contacts can engender perceptions of law enforcement injustice and illegitimacy. ${ }^{213}$ Interestingly, the effect of police contacts is less among AfricanAmerican youth than Latino youth, likely because of African Americans' "experience of the expected," while African Americans who live in integrated environments are more likely to distrust police, perhaps because the racial disparities in law enforcement are likely to be more salient. ${ }^{214}$

The stigmatization of law-abiding minority group members that is intimately related to racially disproportionate incarceration and minority group perceptions of (il)legitimacy connects up with this discussion. Disproportionate incarceration of African Americans is an important "race-making" factor. ${ }^{215}$ Just as the existence

207 Robert Sampson, Neighbourhood and Community: Collective Efficacy and Community Safety, 11 NEw ECON. 106, 110 (2004).

208 Sunshine \& Tyler, supra note 175 , at 520.

209 Id. at 530-31.

210 Tyler \& Fagan, supra note 175.

211 Jeffrey Fagan \& Tom R. Tyler, Legal Socialization of Children and Adolescents, 18 SoC. JUST. RES. 217, 236 (2005).

212 Id.

213 Hagan et al., supra note 182.

214 Id. at 397-99.

215 This term is borrowed from Professor David James, who has written of the ghetto as a 
of ghettoes (the ultimate referent of the consequences of race, place, and crime) can define and stereotype African Americans in a negative light, prisons in which half of the inmates are African Americans define and stereotype African Americans as criminal offenders. Both ghettoes and predominantly AfricanAmerican prisons are physical constructs that sustain and nourish an AfricanAmerican identity tied up with criminal and deviant behavior and in opposition to "mainstream" (read "law-abiding") American identity. Ghettoes and prisons institutionalize race, and because race becomes the marker of the identity that is created by place, it necessarily affects all African Americans whether or not they reside in inner city neighborhoods of concentrated poverty or in prisons.

As a result, many African Americans must endure suspicion by both minorities and non-minorities alike, poor service, refusals of service, and perhaps most importantly for our argument here, erroneous arrests and accusations by the police. In neighborhoods where a decent, law-abiding adolescent must conform to the oppositional culture of the streets, "to the extent that he takes on the presentation of 'badness' to enhance his local public image, even as a form of selfdefense, he further alienates himself in the eyes of the wider society."216 In the minds of some law enforcement agents, black skin is considered a factor to use to decide whether an individual should be considered a criminal suspect. ${ }^{217}$

For obvious reasons, erroneous arrests are likely to undermine the particular individual's assessment of the legitimacy of the state. But even more important for this discussion, erroneous arrests affect how an individual subjected to them discusses the legitimacy of government with his or her friends. This effect is critical to the normative view of compliance with the law. Erroneously arrested individuals may not argue vigorously that government deserves no respect; however, such an individual is probably much less likely than she would otherwise be to vigorously and positively promote government. This is a negative consequence for a norm-driven view of compliance, particularly in communities where the community structure predicts higher crime levels. To see why, consider again the discussion of cultural organization in a community.

Weak structural social processes facilitate diversity in values and norms governing law-abiding conduct, as Elijah Anderson's work demonstrates. Residents of many inner-city communities must negotiate the clash of inconsistent value systems that dictate acceptable behavior. When the strength of signals

"race-making situation." David R. James, The Racial Ghetto as a Race-making Situation, 19 LAw \& SOC. INQUIRY 407, 420-28 (1994).

216 ANDERSON, CODE OF THE STREET, supra note 60, at 112.

217 See Randall KenNedy, RaCe, Crime, and tHe Law 140-41 (1997) (citing numerous examples of individuals stopped by police most likely because of race); Angela J. Davis, Race, Cops, and Traffic Stops, 51 U. MiAMI L. REV. 425 (1997) (discussing the problem of black motorists being stopped disproportionately due to race); David A. Harris, "Driving While Black" and All Other Traffic Offenses: The Supreme Court and Pretextual Traffic Stops, 87 J. CRIM. L. \& CRIMINOLOGY. 544 (1997). 
supporting government legitimacy wanes, we should expect the level of commitment to compliance to wane as well. Signals supporting law-breaking behavior, on the other hand, even while fewer in number than those supporting law-abiding conduct may be very strong. This phenomenon is likely connected to the relative strength of social networks among community sub groups. Teen peer groups, for example, may not be large in number, but the norms that are generated and transmitted among members of these cohesive groups may be very strong compared to the norms generated and transmitted among more numerous but weakly connected adults. This means that adults interested in transmitting law abiding norms to youths in a community through intergenerational transfer may lose in the norm transmission competition to teen peer groups. ${ }^{218}$ Tyler's work shows that when there are fewer positive signals of government legitimacy within a group to support compliance, opinions of peer groups will take their place. ${ }^{219}$ When peer group opinions support law breaking, there will be a net loss of compliance among members of the stigmatized group. The "code of the street" that has developed in opposition to "mainstream" values is "a cultural adaptation to a profound lack of faith in the police and the judicial system;" 220 in place of a reliance on racist and indifferent law enforcement officials, taking care of oneself-even if it results in violence-becomes a primary indicator of control and respect that supersedes compliance with externally-imposed legal authority. ${ }^{221}$ In sum, the potential for stigma creation generated by the racially asymmetrical distribution of prevalent and long sentences prescribed by law and order cheerleaders to allay the problems that minority crime victims experiences undermines the deterrent potential of these sentences where its needed most. Lawabiding African Americans in poor communities, then, must bear the costs of stigma in exchange for few benefits.

\section{B. Linked Fate and Multiple Roles}

The effect of linked fate among all African Americans and the reality of multiple roles played by individuals who hold very ambiguous positions with respect to the terms "law breaker" and "law abider" in many inner-city communities reinforce the detrimental impact that racial asymmetry in punishment can have on the potential for the law-and-order approach to produce the levels of crime reduction necessary for social organization improvement.

Linked fate refers to the empathy that people have with family and friends. But it can also exist among strangers. In the African-American community, linked fate has its foundation in the fact that the life chances of African Americans

218 For a figure illustrating this process, see Tracey L. Meares, It's a Question of Connections, 31 VAL. U. L. REV. 579, 592 (1997).

219 TyLER, supra note 182, at 20-27, 44-45, 58.

220 ANDERSON, CODE OF THE STREET, supra note 60, at 34.

221 Id. 
historically have been shaped by race. ${ }^{222}$ The long history of race-based constraints on life chances among blacks generates a certain efficiency in evaluating policies that affect minority individuals. Many African Americans may use what Michael Dawson calls the "black utility heuristic" to determine what in their best interests. The heuristic allows an individual to determine what is in her individual interests by relying on what is in the best interests of the group. ${ }^{223}$ Whether familial, social, or racial group links are considered, the outcome is likely to be the same. Minority residents of the inner city are less likely to condemn the law breakers among them when they experience critical bonds with them. This bonding process clearly undermines the crime reduction power of the law and order approach to law enforcement.

The multiple roles that many inner-city residents play with respect to the categories "law breaker" and "law abider" also undermine the efficacy of deterrence policies based solely on formal punishment. The lines between law breakers and law abiders are not so clean and clear as promoters of formal punishment often suppose. Multiple roles are inevitable in poor, structurally weak communities where it is not uncommon for law-abiding citizens to decry lawbreaking even as they rely on law breakers for necessary goods such as money and security. If there are few well-paying employment opportunities in poor communities, drug trafficking offers the promise of work and monetary benefits. ${ }^{224}$ Families that do not condone illegality might believe that they have to choose between a shrinking social safety net or the illegal proceeds of drug transactions to feed and clothe children.

Multiple roles are inevitable for another reason. In many cases victims in poor communities are themselves law breakers in the more conventional sense. Some individual victims in high crime inner-city neighborhoods, especially young men, are not always victims. Instead they oscillate between being a victim in one instance and an offender the next.

The ambiguity surrounding the terms "law breaker" and "law abider" in communities that are not well-organized to resist crime can confound the aims of those who promote increased imprisonment. When lines cannot be easily drawn between law abiders and law breakers, a regime tethered to the power formal sanctions to produce deterrence will be forced to raise the price of crime very high indeed to insure differentiation between the two groups. Raising the price of crime through increasing the severity of sanctions and perhaps the certainty of sanctions,

222 See Michael. C. Dawson, Behind the Mule: Race and Class in American Politics 77 (1994) (explaining the linked fate concept as a means of explaining the way that African Americans perceive what is in their individual self-interest.).

${ }^{223} I d$. at 10-11 (explaining that when race over-determines an individual's life chances, it is much more efficient for that individual to use the relative and absolute status of the group as a proxy for individual utility).

${ }^{224}$ There are numerous accounts of the importance of drug selling as an important economic activity in inner-city communities. See, e.g., WILSON, supra note 54; REUTER ET AL., supra note 143; Venkatesh, supra note 81. 
though, creates an extreme risk of asymmetry in punishment that can undermine crime reduction through stigma generation.

\section{DETERRENCE AND THE POLITICS OF PUNISHMENT}

In the U.S., the political demand for punishment often has reflected the cyclical nature of social problems and social change. In particular, a series of "moral panics" about social deviance have captured Americans' political attention and imagination for nearly two centuries, embracing such problems as "unruly" immigrant children, alcohol and drug problems, drunk drivers, child molesters, juvenile delinquency and street gangs, and more recently, youth and domestic violence. ${ }^{225}$ Historically, these growth spurts in imprisonment reflects trends in the criminalization of deviance or the management of the so-called dangerous classes. $^{226}$ The opening of the House of Refuge in New York in 1824, for example, was in part to reaction to problems of unsupervised youth in poor neighborhoods resulting from immigration and in-migration during the rise of manufacturing industry. ${ }^{227}$ Over time, the expansion of child welfare and mental health systems reflected the demand for non-custodial forms of social control, seen on the one hand as benign alternatives to institutionalization, but alternatively as an expanding state apparatus of social control. ${ }^{228}$

Incarceration rates rose sharply beginning in the 1970s. Several political and social trends fueled this increase, contributing to a cycle of political and social demand for punishment. Frustration with rising crime rates, especially homicide and "street" crimes such as robbery, together with social upheavals generally, helped launch a conservative era of crime politics, beginning with the Safe Streets Act of $1968 .{ }^{229}$ However, while homicide rates rose steadily beginning in the 1960s and declined through the 1990s, nearly all the increase and decline was in

225 Joseph R. Gusfield, The Culture of Public Problems (1981); John R. Sutton, STUBBORN CHILDREN: CONTROLLING DELINQUENCY IN THE UNITED STATES, 1640-1981 (1988); DAVID

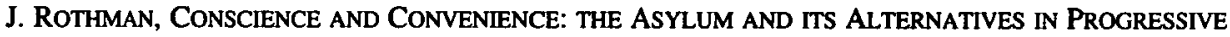
AMERICA (1980); Craig Reinarman \& Harry G. Levine, Crack in Context: Politics and Media in the Making of a Drug Scare, 16 CONTEMP. DRUG PROBS. 535 (1989).

${ }^{226}$ See Anthony M. Platt, The ChILd SAVers: The Invention of Delinguency (1969); GeORge RusChe \& OTto KIRCHHEIMER, PUNISHMENT AND SOCIAL STRUCTURE 5 (1939). They argue that the similarities of regime, organization, and structure across institutions of social control including factories, "workhouses" and prisons, are the consequence of their strategic overlap and interrelated function with respect to the management of the so-called dangerous classes.

227 PlatT, supra note 226; DAVID J. ROTHMAN, THE DisCOVERY OF THE ASYLUM: SOCIAL ORDER AND DISORDER IN THE NEW REPUBLIC (1971); DAVID S. TANENHAUS, JUVENILE JUSTICE IN THE MAKING (2004); JUdTTH SEALANDER, THE FAILED CENTURY OF THE CHILD (2003).

228 Paul Lerman, Deinstitutionalization and the Welfare State (1982); see also FOUCAULT, supra note 29.

229 KATHERINE BECKETT, MAKING CRIME PAY: LAW AND ORDER IN CONTEMPORARY AMERICAN Politics (1997); ElliotT CURRIE, CONFRONTING CRIME (1985). 
gun homicides. ${ }^{230}$ The same pattern was observed for gun robberies: and assaults. ${ }^{231}$ While many legislators reacted to a violence epidemic, in fact the epidemiology of violence for nearly three decades suggested a contagious epidemic of gun violence that was most disproportionately concentrated in poor and minority communities. While lethal and near-lethal violence rose and fell cyclically, rates of non-lethal violence and other crimes remained relatively flat since the early $1970 \mathrm{~s}^{232}$

Despite good evidence of cyclical patterns of contagion and violent crime, a variety of social constructions of the "violence" problem have been advanced, each one justifying new demands for "tougher" sentences and increased punishment. For example, increases in violent crime in the 1960s were attributed to sharp increases in heroin addiction in large U.S. cities, ${ }^{233}$ in the 1970 s to youth violence, ${ }^{234}$ and in the 1980 s to youth gangs, guns, and drug traffickers. ${ }^{235}$ Each successive iteration of the etiology of rising violence rates lead to the identification culturally, politically and socially of new "dangerous classes" that threatened public safety and whose crimes merited increased doses of punishment. Similar trends were identified in the United Kingdom. ${ }^{236}$

Importantly, the "dangerous classes" of the last two decades were "raced." That is, crime became inextricably linked to African Americans, and AfricanAmerican men, in particular. Thus, the escalation in imprisonment can be read not only as a reaction to the changing nature of violent crime and the country's changing mores regarding drug offending, but it also can be read as a statement regarding mainstream society's linkage of African-American men with crime. This phenomenon is not confined to non-African Americans. The crystallization of the connection between African-American men and criminality (that high levels

230 Jeffrey Fagan, Franklin E. Zimring \& June Kim, Declining Homicide in New York City: $A$ Tale of Two Trends, 88 J. CRIM. L. \& CRIMINOLOGY 1277, 1289-90 (1998) (showing that non-gun homicide rates were unchanged over a 30-year period while gun homicide rates rose and declined cyclically over the same period of time). See also ZIMRING \& HAWKINS, supra note 7, at 21-24; Alfred Blumstein, Disaggregating the Violence Trends, in THE CRIME DROP IN AMERICA 13 (Alfred Blumstein \& Joel Wallman eds., 2d ed. 2005).

231 Jeffrey Fagan, Deanna L. Wilkinson \& Garth Davies, Social Contagion of Violence, in THE CAmbridge Handbook of Violent Behavior and AGgRession 688, 694-97 (Daniel J. Flannery, Alexander T. Vazsonyi \& Irwin D. Waldman eds., 2007) (showing similar patterns and trajectories of gun and non-gun lethal and non-lethal violence).

${ }^{232}$ Id at 698-700. See also Richard Rosenfeld, Patterns in Adult Homicide: 1980-1995, in THE CRIME DROP IN AMERICA, supra note 230, at 130, 135-43.

233 Jan M. Chaiken \& Marcia R. Chaiken, Drugs and Predatory Crime, in Drugs AND CrimE 203, 203 (Michael Tonry \& James Q. Wilson, eds., 1990). For data on England, see NICHOLAS DoRN, KARIM MURI \& NIGEL SOUTH, TRAFFICKERS: DRUG MARKETS AND LAW ENFORCEMENT (1992).

234 Paul A. Strasburg, Violent Delinguents (1978).

235 Alfred Blumstein, Youth Violence, Guns, and the Illicit-Drug Industry, 86 J. CRIM. L. \& CRIMINOLOGY 10 (1995); James Q. Wilson, Drugs and Crime, in DRUGS AND CRIME, supra note 233 at 521 .

236 See Beatrix Campbell, Goliath: Britain's Dangerous Places (1993). 
of incarceration promote) engenders distrust within African-American communities. The Reverend Jesse Jackson is not unique among African Americans in fearing victimization by young African-American men. ${ }^{237}$

Weakening of already compromised social structures in poor communities and increased detachment of African Americans generally from government and political participation is a high price to pay for the American commitment to the "get tough" crime control policy. The growth of punishment during the last decade created another paradox: allocations to punishment increased during an era of declining public resources and strains on a wide range of services. ${ }^{238}$ Arguably, in a zero-sum game of public financing, funds allocated to punishment were de jure reductions in allocations to other services. Some of this was fueled by economic circumstances and the realities of state and municipal finance: declining tax bases, increasing drains on budgets for health care and social welfare, reduced federal assistance. It also occurred in a political context of declining confidence in public institutions such as schools and social service agencies. The defunding of services affected social areas and groups who were most involved in punishment, either directly or through family and kinship relationships.

Here, then, is the paradox: the growth of punishment and the correctional industry resulted in the transfer of resources away from the mediating institutions and sources of social control that form the structure of informal social control that are so critical in the high crime communities we have discussed. A steadily weakening structure of informal social control gives rise to the need for increased investments in formal social control, often in the form of formal punishment. Both public and private corrections have flourished in the past decade as this cycle accelerated in the U.S. The demand for punishment provided political support (or cover) for rapid and unprecedented prison expansion. This demand, expressed in the legislatures, at the polling places and through reciprocity between popular culture and political institutions, is what von Hirsch calls "law and order" populism. ${ }^{239}$ This populism increased markedly during the period of prison expansion and defunding of informal sources of social controls. Ironically, the same institutions that serve as informal social control also were the same institutions that in the past could mediate the demand for punishment. In the absence of viable mediating mechanisms, there was unfettered expansion of punishment and corrections.

The decline in confidence in public institutions not only diverted resources from institutions such as health care and schools, but it also bifurcates public sector reaction to rising crime rates. Faced with a crisis of crime, societal reaction could take several directions. One direction might be toward increased punishment and formal control. That is, the state could react by increasing its punitive-control

237 See Richard Cohen, Common Ground on Crime, WASH. Post, Dec. 21, 1993, at A23.

238 See generally MAUER, supra note 5; WESTERN, supra note 5.

239 See Andrew von Hirsch, The Logic of Prison Growth, 57 MoD. L. REV. 476, 478 (1994) (book review). 
apparatus. Another direction might involve ameliorative and preventive reactions that emphasize the state's role in socialization and social development. ${ }^{240} \mathrm{~A}$ third direction might be to pursue a decentralization of state functions of control ceding responsibility to private institutions. The public response in the U.S. has taken the direction of an increased state role in punishment and formal control. Nowhere in contemporary crime policy is there recognition of a public sector role to strengthen informal mediating institutions of socialization and informal control. Instead, public responses were bifurcated: increased allocation of state resources to punishment, coupled with highly localized populist "watchman" forms of informal control such as surveillance mechanisms, block watches, and the criminology of "place." The conservative politics of this era redefined the state role in crime control away from socialization and social development and toward punishment. And prevention through technology replaced prevention through socialization and social control, with the former ceded to the private sector.

The expansion of punishment institutions was the result initially of a political demand for punishment, but recent analysis suggests that the demand for punishment now is sustained by the industry itself. ${ }^{241}$ While the demand for punishment may have its origins in "law and order populism," its current support is sustained through complex political processes that involve the cultural mobilization of resentments against disapproved behavior, and against populations that invoke fear. ${ }^{242}$ But popular support for expanding corrections through "law and order populism" also gave rise to a correctional industry has become an autonomous source of demand for punishment. These institutions have achieved a threshold where they have the motivations and means for perpetuating the political processes that sustain a continuous expansion, and that redistribute public resources away from mediating institutions toward correctional ones.

This drain will insure that mediating institutions remain weak relative to legal institutions, continuing the cycles that contribute to the demand for punishment. A recent study by the California Policy Research Center at the University of California showed that corrections spending continued to match $\mathrm{K}-12$ education spending in California as recently as $2006 .{ }^{243}$ While that projection was not

${ }^{240}$ While this response now seems the province of the far-left, the moderate establishment figures endorsed this type of idea when looking to increased opportunities for urban African Americans and an attack on racial discrimination. "There are those who oppose these aims as 'rewarding the rioters.' They are wrong. A great nation is not so easily intimidated. We propose these aims to fulfill our pledge of equality and to meet the fundamental needs of a democratic, civilized society-domestic peace, social justice, and urban centers that are citadels of the human spirit." THE KeRNER REPORT, supra note 176, at 413.

241 Nils Christie, Crime Control as Industry ( $3 \mathrm{~d}$ ed. 2000).

242 von Hirsch, supra note 239 , at 481.

243 Joan Petersilia, California Policy Research Center, Understanding California CORRECTIONS $1, \quad 15-17 \quad$ (2006), available at http://ucicorrections.seweb.uci.edu/pdf/UnderstandingCorrectionsPetersilia20061.pdf. See also Thomas D. Stucky, Karen Heimer \& Joseph B. Lang, A Bigger Piece of the Pie? State Corrections Spending and the Politics of Social Order, 33 J. RES. CRIME \& DELINQ. 91 (2007). 
ultimately realized, budget projections show that corrections spending will overtake higher education spending there by $2013 .^{244}$ Among African-American men, however, that milestone seems distant; there are already four times as many black men incarcerated in the state's prisons as enrolled in public universities, even as the lack of new colleges limits access of tens of thousands of Californians to public higher education. ${ }^{24}$ This possibility is all the more remarkable in light of the political activism and high levels of electoral campaign contributions of the union of correctional officers in California. ${ }^{246}$

\section{CONCLUSION}

The continuing social restructuring of work and community will maintain political tensions that give rise to escalating demand for formal punishment, at the same time that this same restructuring weakens the forms of informal controls that formal controls would supplant. The allocation of resources from informal to formal social controls, particularly punishment through incarceration, sustains a process that contributes to the marginalization of already isolated communities and individuals, further weakening informal controls and continuing the cycle of discontrol and punishment.

In many communities, punishment has become normative, losing its contingent value that lends credibility to its claims of fairness and proportionality. ${ }^{247}$ As the social and cultural distance between the punishers and the punished continues to widen, respect for the legitimacy of punishment will suffer. This is one source of the perverse escalatory effects of punishment, and a source that appears unlikely to abate in a continuous process of deindustrialization and restructuring of work. The globalization of economic restructuring will sustain the political basis for the expansion of punishment: disquiet in the popular culture will continue as economic uncertainty fuels suspicion and rejection of marginalized or alien populations.

What passes for "control" today in the U.S. is an odd combination of large correctional institutions and elaborate networks of surveillance systems: cameras,

244 James Sterngold, Prisons' Budget to Trump Colleges', S.F. CHRONICLE, May 21, 2007, at Al.

245 Elliot Currie, Race, Violence, and Justice since Kerner, in LOCKED IN THE POORHOUSE: Cities, Race, AND PoverTy IN THE United States 95, 114-15 (Fred. R. Harris \& Lynn A. Curtis eds., 1998).

246 See Stucky et al,, supra note 243; Dan Morain, Potent Prison Guards Union Facing Challenges to Status Quo, L.A. TIMES, Jan. 5, 2004, at B-1, available at http://articles.latimes.com/2004/jan/18/local/me-guards18; Dan Walters, California Prison Guards Union, Indian Tribes Flex Political Clout, MODEsto BEe, Aug. 28, 2008, available at http://www.modbee.com/opinion/state/dan_walters/story/411165.html.

247 Nagin, supra note 12, at 23 (constructing a theory of "stigma erosion," where high rates of imprisonment make punishment non-contingent and socially meaningless, and therefore an ineffective deterrent). 
urine testing devices, infrared detectors, and so forth. De-emphasized is the state's role in socialization and the fostering of moral communities. The devolving of the public sector involvement in socialization, and the continuing privatization of "security," will further weaken informal social controls and mediating institutions. This restructuring and devaluation of government, accompanied by the restructuring and fragmentation of economic activity, makes difficult the achievement of a social consensus on the rationale of punishment in a broader context of social control. How will the reintegrative functions of punishment be achieved when social functions are limited to those essential only to economic, but not social, well-being? $?^{248}$

Historically, punishment has been part of social control when formal and informal social controls are reciprocal and complementary, and when punishment is perceived as fair substantively and procedurally. Punishment has thrived independently of social control in the political context of weak government that assumes no role in other social functions. This paradoxical affinity of punitiveness and weak government points the way toward new policies that will reverse the weak if not iatrogenic effects of punishment with respect to crime. The reconfiguration of criminal justice along lines of reintegrative justice, substantive rationality, and proportional and procedural fairness, is one large step. Social and economic policies designed to produce social and human capital will strengthen the moral basis of punishment, and paradoxically, reduce the demand for it. 
